\title{
Media views of the Stromboli 2002-2003 eruption and evacuation: a content analysis to understand framing of risk communication during a volcanic crisis
}

\author{
Laura Calabrò ${ }^{*}$, Andrew J. L. Harris ${ }^{2}$ and Jean-Claude Thouret ${ }^{2}$
}

\begin{abstract}
The 2002-2003 eruption of Stromboli (Aeolian Islands, Italy) was one of Stromboli's most important effusive events of the last two centuries and began on 28 December 2002. On 30 December 2002, two days after the beginning of the eruption, a landslide entered the sea and caused a tsunami that struck Stromboli's coastal areas. The events of 30 December led to a "voluntary evacuation" by Stromboli's inhabitants. To understand the role of the media in framing risk and the evacuation, we analyzed the content of five newspapers, including two national newspapers (II Corriere della Sera and La Repubblica) and three regional newspapers (La Gazzetta del Sud, La Sicilia and II Giornale di Sicilia), published during the period covering the onset of the eruption, the tsunami and the voluntary evacuation (28 December 2002-18 January 2003). Our aim was to assess the type of hazard information given, how it was delivered, and how this may have helped (or not) with the population's resilience, especially in regard to viewing a potential need to evacuate in a favorable light. News regarding the eruption covered a total area of 12 , $000 \mathrm{~cm}^{2}$ for the national newspapers $\left(\sim 6000 \mathrm{~cm}^{2} /\right.$ paper) against $41,700 \mathrm{~cm}^{2}$ for the regionals $\left(14,000 \mathrm{~cm}^{2} /\right.$ paper); making the regional newspapers the more important sources by quantity. For both newspaper categories, most of this area was occupied by interviews with experts, followed by quotes from residents and tourists, and, finally, those involved in the response (i.e., hazard managers, including civil protection and local government). Out of a total of 9286 words analyzed, the most popular was "tsunami" (426 cases), with the word "volcano" being repeated 315 times (the 6th most popular word); so it would have been difficult for the population not to have known there was a potential risk of tsunami associated with the volcano. In texturally framing the eruptive crisis, negative words, such as "fear", "terror" and "apocalypse", were much more frequent than positive words, which were rare and even not present in some newspapers. The reporting focused on the tsunami threat with little link back to the eruption and other hazards, and contrasted with imagery (that took up $41 \%$ of the reporting space) which comprised relaxing pictures of a tranquil island surrounded by a calm blue sea. This, coupled with a confused message through selection of quoted expert sources, may have led to an exaggerated and alarmist frame for the eruption and attendant hazards. This was in spite of widespread use of scientific sources, as well as pleas from the (Continued on next page)
\end{abstract}

\footnotetext{
* Correspondence: laura.calabro@uniroma3.it

'Dipartimento di Scienze Geologiche, Universita' di Roma TRE, Largo S.

Leonardo Murialdo 1, 00146 Rome, Italy

Full list of author information is available at the end of the article
}

\section{$\triangle B M C$}

(c) The Author(s). 2020 Open Access This article is licensed under a Creative Commons Attribution 4.0 International License, which permits use, sharing, adaptation, distribution and reproduction in any medium or format, as long as you give appropriate credit to the original author(s) and the source, provide a link to the Creative Commons licence, and indicate if changes were made. The images or other third party material in this article are included in the article's Creative Commons licence, unless indicated otherwise in a credit line to the material. If material is not included in the article's Creative Commons licence and your intended use is not permitted by statutory regulation or exceeds the permitted use, you will need to obtain permission directly from the copyright holder. To view a copy of this licence, visit http://creativecommons.org/licenses/by/4.0/ The Creative Commons Public Domain Dedication waiver (http://creativecommons.org/publicdomain/zero/1.0/) applies to the data made available in this article, unless otherwise stated in a credit line to the data. 


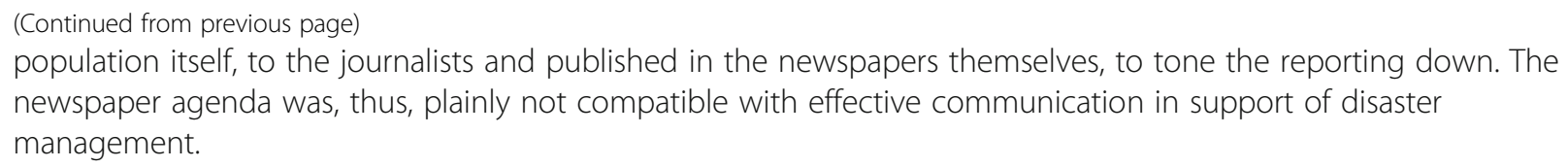

Keywords: Newspaper, Frame, Volcanic eruption, Tsunami, Risk, Reporting

\section{Introduction}

Communication during a natural disaster has been described as an exchange of information among experts, public administrations, mass media, interest groups and citizens, with the aim of helping to make appropriate decisions about accepting, reducing or avoiding the risk (Haynes et al., 2008; Leiss, 1996). The management of several infamous volcano eruption crises (e.g., Soufriere de Guadeloupe, West Indies in 1976; Nevado del Ruiz, Colombia, in 1985; and Fuego, Guatemala, in 2018) have shown the importance of communication in positively, or negatively, framing scientific understanding of an eruptive event and the effectiveness of disaster management interventions to the wider public. Bretton et al. (2018) note that poorly-handled scientific communication can cause "social, economic and political problems, and undermine community confidence in disaster management regimes". For example, well-publicised scientific and political disagreements during the 1976 eruption of La Soufrière caused stigma that still has strong influence in framing of future volcanic crises on Guadeloupe, FWI (Hincks et al., 2014) or elsewhere in France or Europe. In contrast, during the lahar events from Nevado del Huila (Colombia) in 2006 effective communication between experts and politicians saved hundreds of people (Fearnley et al., 2018). Because most of the information that people receive on risk is through communication rather than direct experience, correct communication of risk and disaster management measures is a fundamental component of mitigation and for risk reduction (Barclay et al., 2008; Gaillard and Dibben, 2008; Sigurdsson et al., 2015; Loughlin et al., 2015). However, due to the difficulties in comprehension and translation of a risk message during passage of information between different actors in the communication chain, often scientific and disaster management-information becomes distorted and/or misunderstood (Block and Keller, 1995; McClure and Sibley, 2011; Leonard et al., 2014; Linville et al., 2015).

Several studies have shown how mass media can be used as a channel for emergency management agencies (such as civil protection, local government, law and order departments, rescue services, etc.) to inform people on the current status of a crisis or to diffuse information (e.g., Stieglitz et al., 2018; Joseph et al., 2018; Harris and Villeneuve, 2018a; Hicks et al., 2017; Doyle et al., 2014). The media have become, therefore, one of the most powerful, and important, risk communication channels. Due to the frequency, quantity and wide availability of mass media information, the mass media have long been considered able to influence public understanding of, and the way they think about, a topical issue (e.g., Lippmann, 2008; Katzman, 1972; McCombs, 2014), as well as the perception of, and potentially the actions made by, populations in the face of a natural disaster (Wilson, 1995; Boykoff, 2007; Stieglitz et al., 2018) despite well-known credibility concerns. Media professionals, in fact, decide which topics to cover and how much coverage should be dedicated to them (Reese et al., 2001). Placement also influences the importance given to the news by the public, for example, whether the event is reported on the front page versus an inside page in a newspaper (Harris, 2015). Further, the type of words and imagery used to portray the topic will aid in setting the event frame (Harris and Villeneuve, 2018b). In filtering risk communication, the media will thus provide a fundamental role in setting the frame for the natural disaster, as well as the way scientists and hazard management specialists and their communications are perceived (Harris et al., 2012). Fundamentally, to be reported-on the event must fit the news values of the media source (Harcup, 2009). Namely whether the communication is helpful, or not, in terms of effective risk communication, will depend on the media's agenda, and their value systems the publisher wishes to enforce (Katzman, 1972, McCombs and Shaw, 1972; Vu et al., 2014). Unfortunately, these sets of values are not aimed at managing risk, but rather to make stories appealing to the readership so as to-after all-sell the newspaper. The result is often sensationalization, exaggeration, selection and spin (Harris et al., 2012; Harris 2015).

In this paper we thus focus on this issue of risk communication through the media. To do this we further develop a method, based on a merge of media tracking methods and frameworks laid out in Harris (2015) and Harris and Villeneuve (2018a,b), to better understand the quantity and type of information readerships receive during a volcanic crisis. In particular, we focus on how selection and use of text, imagery, sources and data can positively or negatively frame the risk, and lead to media-based distortion. To do this, we conducted a content analysis of five newspapers published during a 22- 
day period spanning the first 3 weeks of the 2002-2003 eruption of Stromboli (Aeolian Islands, Italy). We chose this eruption as it was a somewhat unexpected event scenario for which the population, scientists, disaster managers and media were not prepared. Prior to December 2002, this group of actors had been used to Stromboli being associated with regular (13 events/hour), small (less than $6000 \mathrm{~kg} / \mathrm{event}$ ) explosions sending ejecta to heights of only 50-150 m (Ripepe et al., 2008); such events just affected the crater area and were punctuated by occasional (short and small volume) effusive events (Barberi et al., 1993). The summit area, prior to the 2002-2003 eruption, had thus remained open to tourists with no restrictions. The ease of visit to the summit and guarantee of viewing of explosive activity, along with Stromboli's fame as a classic volcanological site, made Stromboli an iconic volcano tourist destination (Struck, 2010), where the tourist industry had developed "with little consideration being paid to the hazards posed by the presence of an active volcano" (Bertolaso et al., $2008 \mathrm{a}, \mathrm{b})$. Indeed, by 1989 , although the population was only around 421, hotel bed capacity was for 1181 with almost 21,000 tourists staying on the island during the year (Cavallaro and Concotta 1991). Instead, the landslide of 28 December 2002, and the tsunami it generated, required a re-assessment of hazard, risk, response, safety and preparedness (Bertolaso et al., 2009), as well as public perception and access and, hence, communication.

\section{The first three weeks of Stromboli's 2002-2003 eruption and media coverage}

Stromboli's 2002-2003 eruption began on 28 December 2002 following several months of heightened summit (normal explosive) activity (Burton et al., 2008). Initial activity involved emission of lava from a fracture that opened between the NE rim of crater area, at an elevation of $750 \mathrm{~m}$ a.s.l., and the $600 \mathrm{~m}$ elevation on the Sciara del Fuoco (Fig. 1). Lava flow fed at high (up to $280 \mathrm{~m}^{3} / \mathrm{s}$ )

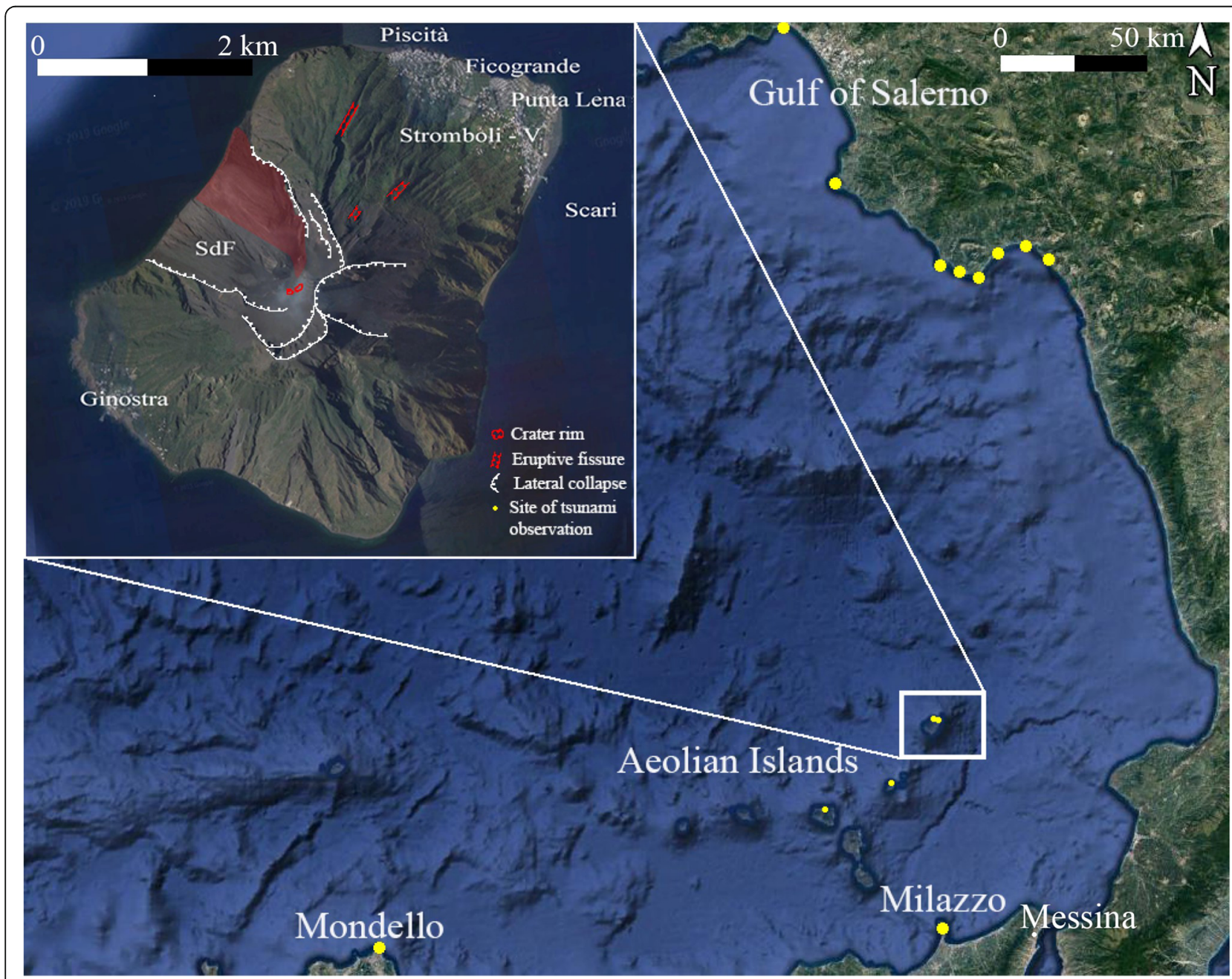

Fig. 1 Geographic location map of the Island of Stromboli. The rectangle encloses the zoomed area, where SdF: Sciara del Fuoco. Stromboli-V: Stromboli village. Red area: lava flows. Tsunami sites of observation are from Maramai et al. (2005a) 
effusion rates rapidly advanced to the coast, but remained in the unpopulated collapse scar of the Sciara del Fuoco (Calvari et al., 2005). Such effusive activity was nothing new, previous effusive events having emplaced lava flows between the summit craters and the sea in 1985-1986 (De Fino et al., 1988) and November 1975 (Capaldi et al., 1978). It was thus treated as a spectacular development of the normal activity which, today, furnishes eye-catching images for use in post-card sales (Fig. 2) and guide book entries, as in that of Rachelli (1998) which was widely available on the island at the time of the eruption.

However, on 30 December 2002, 2 days after the beginning of effusive activity, a new fracture formed along the Sciara del Fuoco, causing the detachment of two large $\left(10^{6}-10^{7} \mathrm{~m}^{3}\right)$ portions from the Sciara del Fuoco (Bonaccorso et al., 2003; Pino et al., 2002). The two landslide bodies detached in events that began at 13:14: 05 and at 13:22:38 (local time), respectively (Bonaccorso et al., 2003), and triggered tsunami waves with a maximum run-up of $10.9 \mathrm{~m}$ at Spiaggia Lunga on Stromboli (Tinti et al., 2006a, 2006b). These waves injured three people and damaged buildings and boats along the waterfront at Ficogrande, Punta Lena and Scari (Tinti et al., 2006a, 2008), all located on the NE shore of the island (Fig. 1). The waves also reached Panarea, Milazzo in Sicily (causing two oil tankers anchored in the port to break their anchors) and southern Campania as far as $240 \mathrm{~km}$ from Stromboli. Although several tsunami events were recorded across the Aeolian Islands between 1919 and 1988, and because the last event on Stromboli occurred back in 1944, this phenomenon was something a little more out-of-the ordinary and worrying (Maramai et al., 2005a, b). Not too surprisingly, no postcards available on Stromboli or guide books depict such highimpact events, but instead focus on an idyllic island set in a calm blue sea (e.g. Rachelli, 1998; Clark and Bonetto, 2017; Marca, 2019; Chua, 2013; Leva, 2000) (Fig. 3).
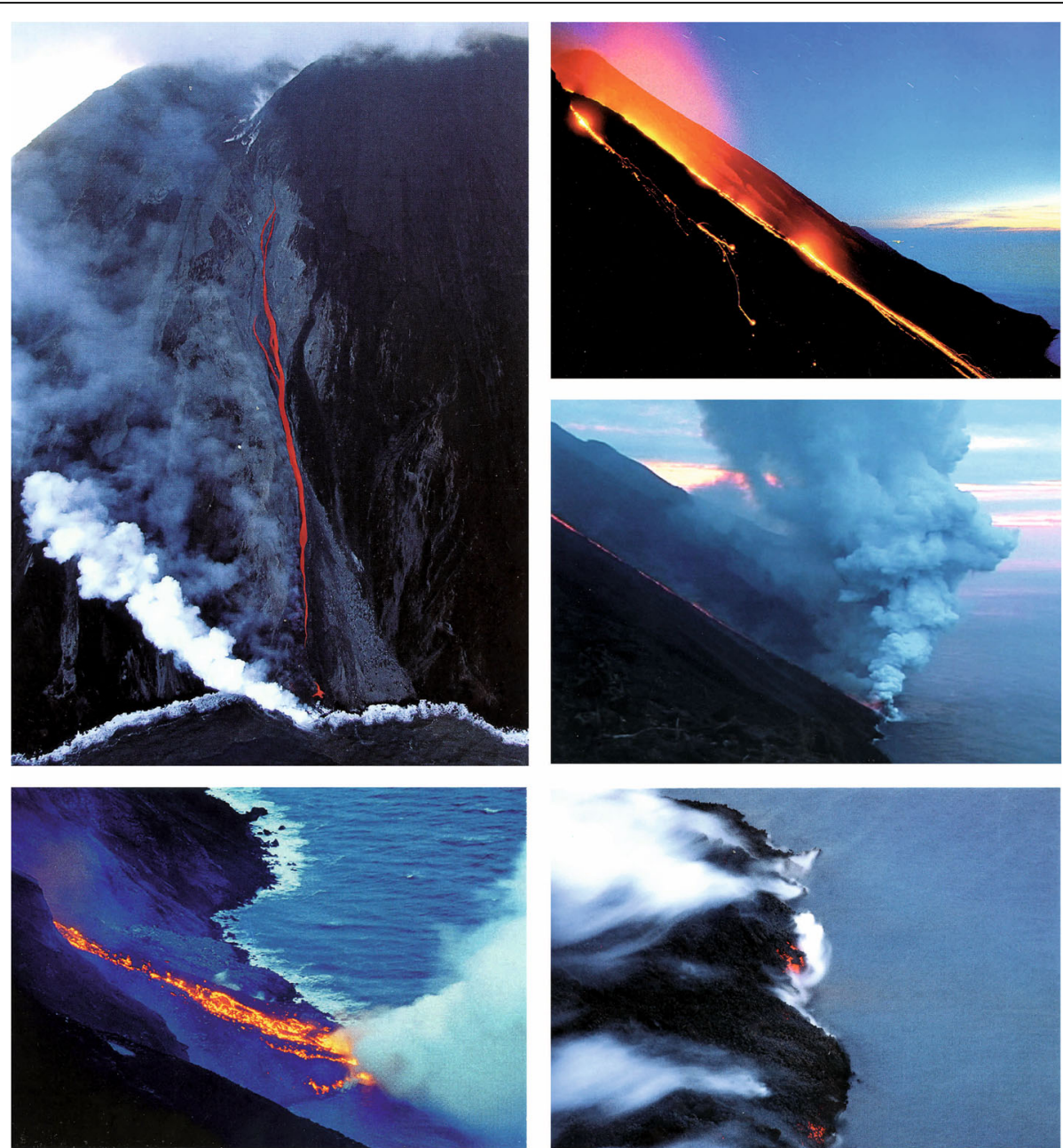

Fig. 2 All postcards available for sale on Stromboli in September 2018 depicting the eruption of 2002-03. We have left the images as given (without scales) so that the viewer sees all that is available in terms of interpretive information 

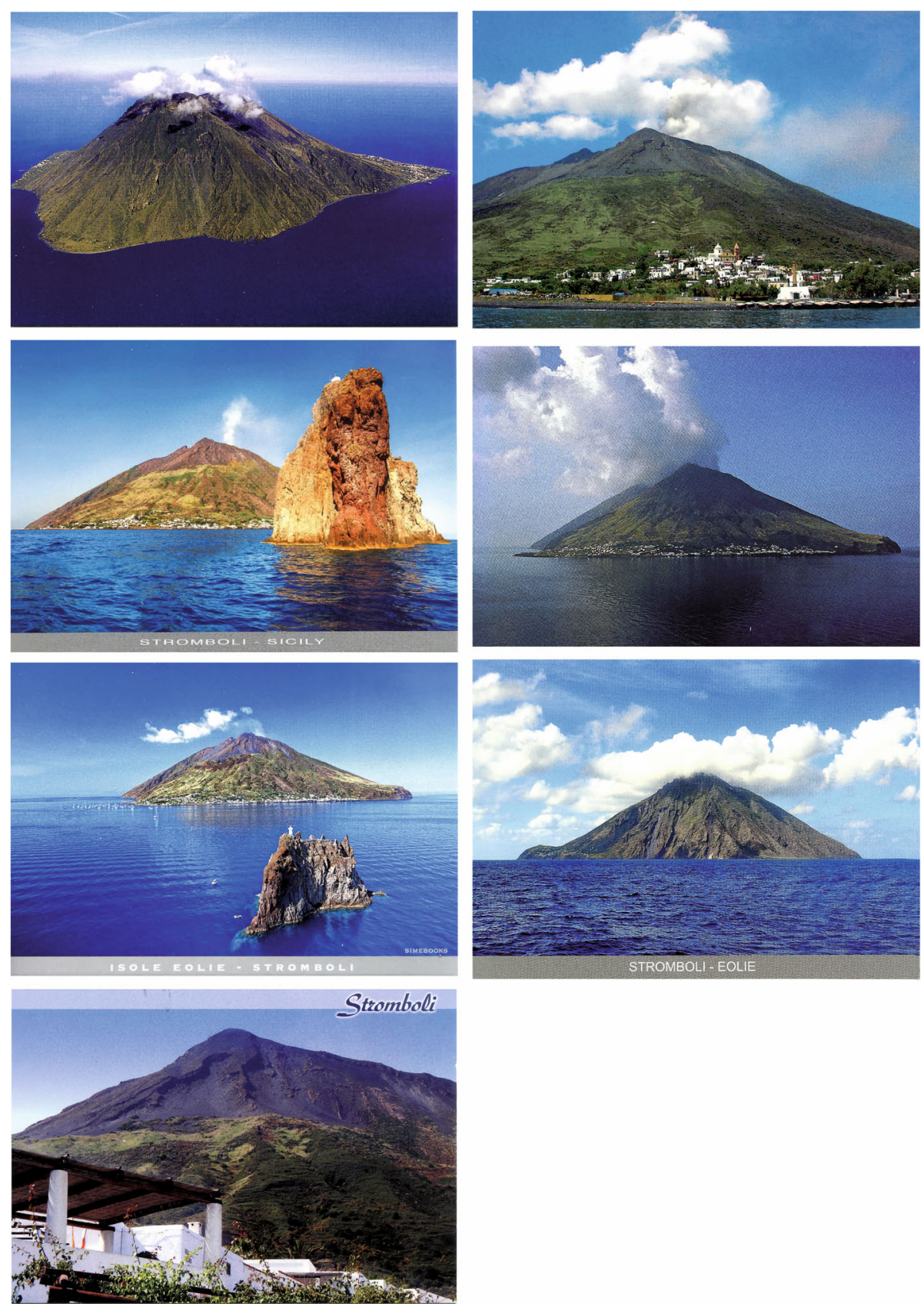

Fig. 3 All postcards available for sale on Stromboli in September 2018 depicting the Island

The same symbolism is even found in fictional writing and children's story books, see for example Di Benedetto (2017). Instead, tsunami warnings and communication are left to formal civil protection-based pamphlets, maps and signage (PMC-DPC, 2008; Bertolaso et al., 2009).

Following the 30 December 2002 event, civil protection intervention was immediate (Bertolaso et al., 2008a, b). The first action was to help residents and provide lodging for those who decided to leave the island spontaneously. On 31 December, about 330 residents decided to evacuate Stromboli; mostly leaving for neighboring islands and Messina where they were catered for by civil protection and the Red Cross. As a result, by January 2003 , there were only 50 residents still living on the island, plus the staff of the monitoring facility, the central operations (monitoring) center (COA) that was installed immediately to provide surveillance (Bertolaso et al., 2008b). Only at the beginning of February did the population return to the island, but the island remained closed to non-residents through mid-March (Bertolaso 
et al., 2008b), while effusive activity continued until July 2003 (Calvari et al., 2005).

Three regional newspapers cover news on Stromboli, these being: La Gazzetta del Sud (Messina), La Sicilia (Catania) and Il Giornale di Sicilia (Palermo). These three newspapers have a combined circulation of around 86,000 newspapers per day (Table 1 ). The eruption onset was deemed sufficiently newsworthy to warrant placement on the front page only in La Gazzetta del Sud and Il Giornale di Sicilia on 29 December 2002. The wording of the headlines also highlighted the spectacular feel to, and familiarity with, the initial events, with the Gazzetta del Sud leading with (La Gazzetta del Sud, 29/12/02, p. 1),

"Stromboli awakens: Last night an impressive eruption occurred resembling that of ' 86 ",

and Il Giornale di Sicilia printing (Giornale di Sicilia, 29/12/02, p. 1),

"Stromboli eruption record: lava flows into the sea".

La Sicilia, however, did not report on the new eruption. Instead, the landslide and tsunami of 30 December made the front page of all three regional newspapers on 31 December, with the headlines reflecting the shock of the new, high-risk and unexpected turn of events:

"Panic in the Aeolian Islands" (La Gazzetta del Sud, 31/12/02, p. 1).

Terror on Stromboli (La Gazzetta del Sud, 31/12/02, p. 1).

On the run from Stromboli (La Sicilia, 31/12/02, p. 1).

The 30 December events also made the front pages of most national newspapers, so that reporting from there-on drew both the regional Sicilian, and wider Italian, public attention to the events unfolding on Stromboli. It also began recording statements from local inhabitants, tourists, politicians, civil protection and scientists, using words and images which would have shaped public opinion while being passed through 'the media filter' (Mathien, 1986; Harris, 2015).

\section{Methods}

To analyse the text reported in the five newspapers, we used content analysis. This is a systematic and objective method of describing and quantifying information contained in written and/or oral communication (Krippendorff, 1980; GAO, 1996; Elo and Kyngäs, 2008). In applying a content analysis, the quantity of information and frequency of most-common words is usually recorded (Neuendorf, 2002). The assumption made is that the words that are mentioned more frequently are those that reflect the greatest concerns. Word position in the text can also be evaluated since certain positions have higher impact than others, e.g., those words appearing in the title or first and/or last sentence of an article will have highest impact. Position of the article in the newspaper itself can also determine the impact, e.g., front page versus inner pages (Harris, 2015). The same can be applied to images, which will advertise the main subject (Naccarato and Neuendorf, 1998), where the size, positioning (on the page), placement (in the newspaper) and selection of imagery are all quantifiable metrics, as are the number and length of words in associated headlines (Harris and Villeneuve, 2018b). Qualitative analysis can then be applied to examine what different meanings emerge as a result of selecting and using-and then linking within sentences, paragraphs and articles-certain information, words and/or images (Nuenendorf, 2002).

In applying these analyses, three units can be considered (Krippendorff, 1980): (i) the sampling unit, which is the unit capable of providing the required information; (ii) the context unit, which is that content that can be described quantitatively; and (iii) the recording unit, which includes all information that cannot be quantified. For the sampling unit we took the three regional newspapers that serve Stromboli (La Gazzetta del Sud, La Sicilia and Il Giornale di Sicilia), plus the two most-read national newspapers (Il Corriere della Sera and La Repubblica), examining all 22 issues of each newspaper available during the three week period spanning 28 December 2002 through 18 January 2003 (Table 1). Today's news will appear in tomorrow's newspaper, so the onset of the eruption should appear on 29 December 2002, with reporting then lagging one day behind the

Table 1 Newspapers selected for the content analysis. Paper circulation and population data are from Istat.it (downloaded on 201805-28 at 10:14 UTC), and number of pages is as counted for the study period. The total area of all news devoted to Stromboli over the 22-day (28 December 2002-18 January 2003) study period is given

\begin{tabular}{llllll}
\hline Newspaper & $\begin{array}{l}\text { Circulation (newspapers per } \\
\text { day) }\end{array}$ & $\begin{array}{l}\text { Circulation (newspapers per } \\
\text { day) }\end{array}$ & $\begin{array}{l}\text { Number of } \\
\text { pages }\end{array}$ & $\begin{array}{l}\text { Single page Area } \mathrm{cm} \times \mathrm{cm} \\
\text { (cm2) }\end{array}$ & $\begin{array}{l}\text { Stromboli Area } \\
(\mathrm{cm} 2)\end{array}$ \\
\hline $\begin{array}{l}\text { II Corriere della } \\
\text { Sera }\end{array}$ & 216569 & $60589445(0.35 \%)$ & 38 to 46 & $53 \times 38.6(2046)$ & 8037 \\
La Repubblica & 175237 & $60589445(0.28 \%)$ & 48 to 52 & $48 \times 35.2(1690)$ & 4250 \\
$\begin{array}{l}\text { La Gazzetta del } \\
\text { Sud }\end{array}$ & 52070 & $5056641(1.02 \%)$ & 32 to 36 & $52 \times 34.2(1778)$ & 23979 \\
$\begin{array}{l}\text { La Sicilia } \\
\text { II Giornale di }\end{array}$ & $19846 \mathrm{c}$ & $5056641(0.39 \%)$ & 43 to 48 & $56 \times 38(2128)$ & 8373 \\
Sicilia & 14527 & $5056641(0.28 \%)$ & 36 to 48 & $47 \times 28.2(1325)$ & 8618 \\
\hline
\end{tabular}


occurrence of the actual event or statement (e.g., Harris and Villeneuve, 2018a, b). For each case, the edition most local to Stromboli was selected, this either being Messina or Catania in Sicily; these being the editions in which most information regarding the eruption crisis on Stromboli should be reported. The newspapers from this period are not available in digital format, but were all available in original hard copy format at the Messina regional library archive. There all issues were searched, and any article reporting on Stromboli recorded into an excel-based log sheet, and a digital photograph taken of the page containing the report. Data recording was completed in the newspaper language (Italian), and later translated to English. From herein we use the English translation, but the full data set in original language is given in Electronic Data Supplement 1 and translations of key headlines and phrases are given in Table 2 .

\section{Context unit: coding and classification for quantitative analysis}

To quantify the information contained in each report, we first recorded the metadata for each article. This involved recording of the host newspaper, date of publication, page number, headline, article number (one being assigned to the first report focusing on Stromboli on any day in the newspaper under analysis, and $\mathrm{n}$ being the $\mathrm{n}^{\text {th }}$ report on that day), and report area $\left(\right.$ in $\mathrm{cm}^{2}$ ). The total page size and number of pages in the newspaper on the day of publication was also recorded. Images were measured separately, and the caption recorded in place of the headline. Because the importance of the news will be reflected by the location of the report in the newspaper, news reported on the front page will have a greater weight than news 'hidden' in the inner pages. Front page news was thus highlighted, and checked as representative of information contained within the newspaper.

Each element of the content of each article was then coded depending on the levels of information contained within the report, with the report being broken down as follows:

Level 1: Headline, sub-title or image caption associated with reporting on Stromboli.

Level 2: Any picture, sketch or map linked to the report;

Level 3: Body text of the article;

Level 4: Quotes and interviews related to the Stromboli eruption.

For levels 1, 3 and 4, all words were recorded and used to carry out word counts and frequency analysis, and all images were photographed and saved for qualitative classification. In addition, for level 4 information, the name and institute/affiliation/domicile of any source (if given) was recorded. From the word lists, we then extracted all words relating to a hazard, activity or response and placed them into five classes, these being:

Class 1: General volcanic (including "activity", "the island", "the village" and "Stromboli"-island or village);

Class 2: Explosive (including normal Strombolian activity and larger events);

Class 3: Effusive (including "lava" and "flow");

Class 4: Landslide (including structural issues and sector collapse);

Class 5: Tsunami (and sea/ocean waves of all types);

Class 6: Response (including mitigation, management measures and evacuation).

All locations and dates/times of occurrence (i.e., any factual information) related to each class was also recorded along with the source of the information (if given). In doing this, synonyms for each class, were recorded and placed into the most appropriate word group. For example, in the Giornale di Sicilia, different synonyms were used to indicate the tsunami, such as "tidal wave", "harbor wave", "anomalous wave", "wall of water" and/or, simply, "wave"; these were all placed into the "tsunami" parent group. As such, for the word frequency count, synonyms were counted as grouped into single parent word categories.

\section{Record unit: coding and classification for qualitative analysis}

To assign meaning, association and/or connotation of any phrase, each context unit needs to be checked against any given qualifier (Webber, 1990). We thus linked all words extracted as context units to their nearest modifier, qualifier, adverb, hyperbolic phase or superlative. This was completed at the level of the phrase in body text sentences (or headlines). We then classified all such cases as either negative, i.e., alarming (e.g., "worse", "hell", "terror") or positive, i.e., reassuring (e.g., "better", "paradise", "quiet"). In addition, images were classified in terms of the dominant theme (island, eruption, volcano), color/tone (blue, red, orange, green, grey, black) and feeling (tranquil, relaxing, frightening, stressful). In this regard, words as well as images can be categorized into groups of similar meaning or connotation (Webber, 1990), and used to assess whether the content has been exaggerated or suppressed (Rowe et al., 2000). Finally, the source of any quoted material was assigned a group, these being:

Source 1: Hazard manager (civil protection plus localregional-national government);

Source 2: Responders (search and rescue, health and security, police/military, etc.);

Source 3: Scientists (observatory staff, invited scientists, academic experts); 


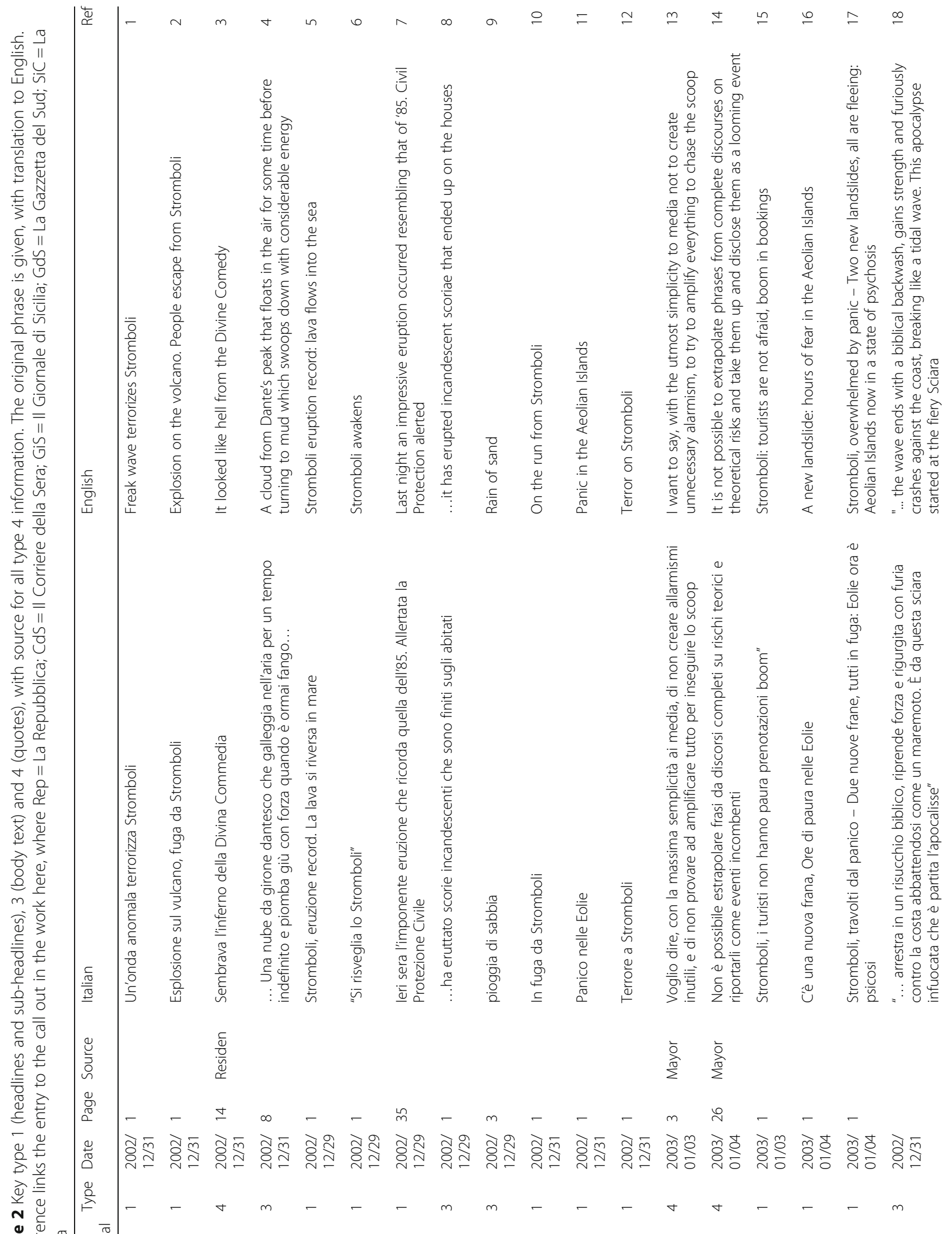

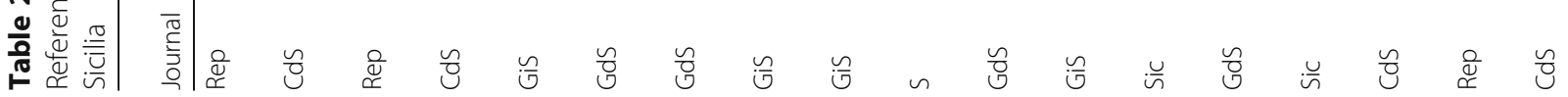




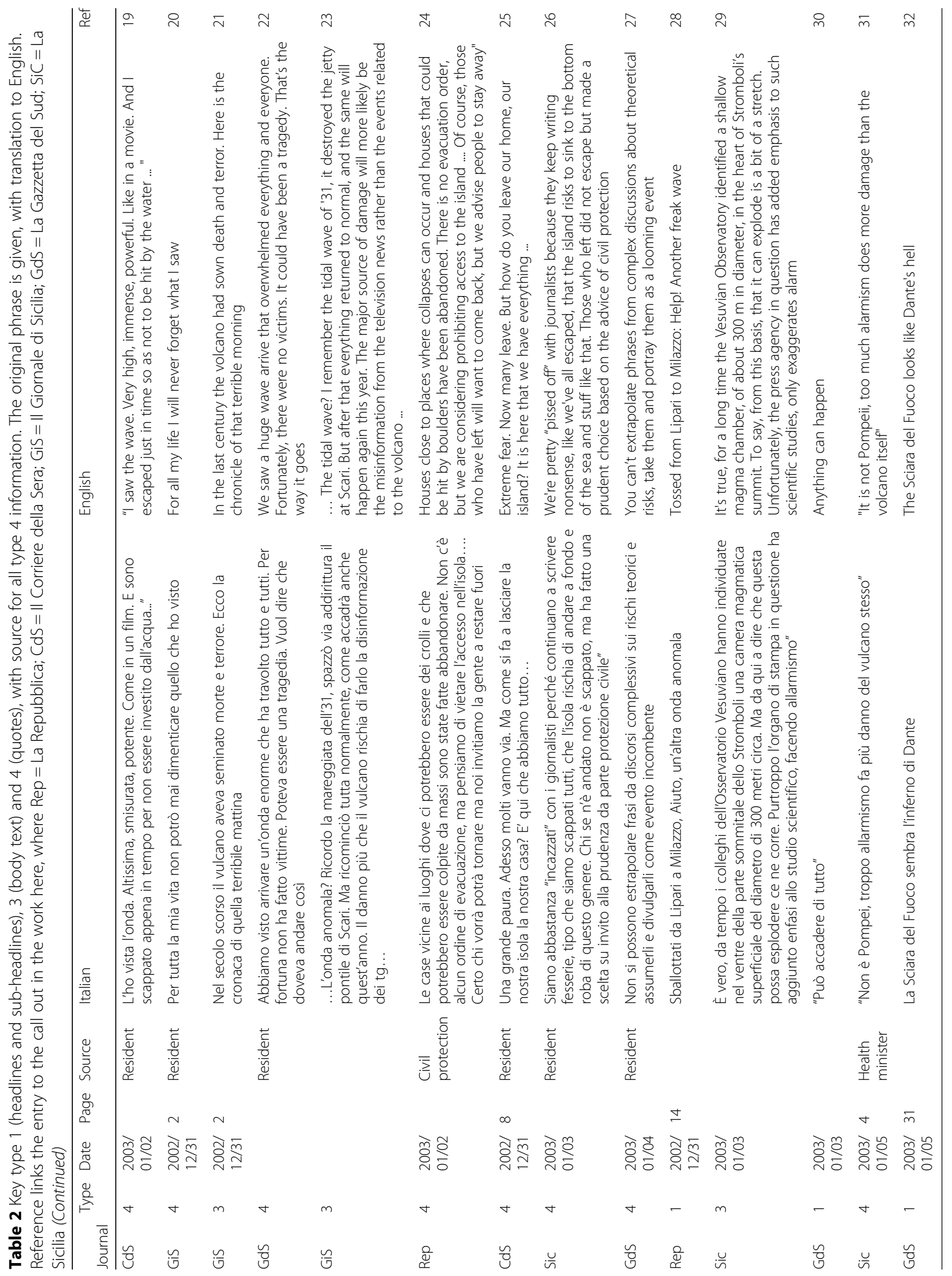


Source 4: Population, which was separated between (a) resident (including guides and tourist operators), and non-resident (i.e., tourists).

These groups broadly follow the call down flow chart of Bertolaso et al. (2009) in which the reporting, assessment, decision making and communication chain for a natural disaster on Stromboli is given. However, this chain omits "journalists" (see Fig. 3 in Bertolaso et al., 2009) whose writing will reach, in the case considered here, nearly half a million people (Tabl 1 ).

\section{Results and discussion}

News regarding the crisis covered a total page space of $53,700 \mathrm{~cm}^{2}$ across the five newspapers considered (Table 1). This is equivalent to an average of around
$0.25 \mathrm{~m}^{2}$ of information per day (over the three weeks study period) which was disseminated to almost half a million people. Of this content $12,000 \mathrm{~cm}^{2}$ of information was contained in the two national newspapers to reach almost 400,000 readers, while $41,000 \mathrm{~cm}^{2}$ of information was published in the three regional newspapers to reach just over 86,000 readers. Of these, the Gazzetta del Sud reported by far most news, accounting for $43 \%$ of the total page space devoted to reporting on the crisis across all five newspapers considered (Table 1). In total 173 reports appeared over the three week-long analysis period, with 138 reports appearing in the regional newspapers, and 35 appearing in the nationals. In all newspapers, peak coverage occurred on 31 December 2002 (Fig. 4). Although the

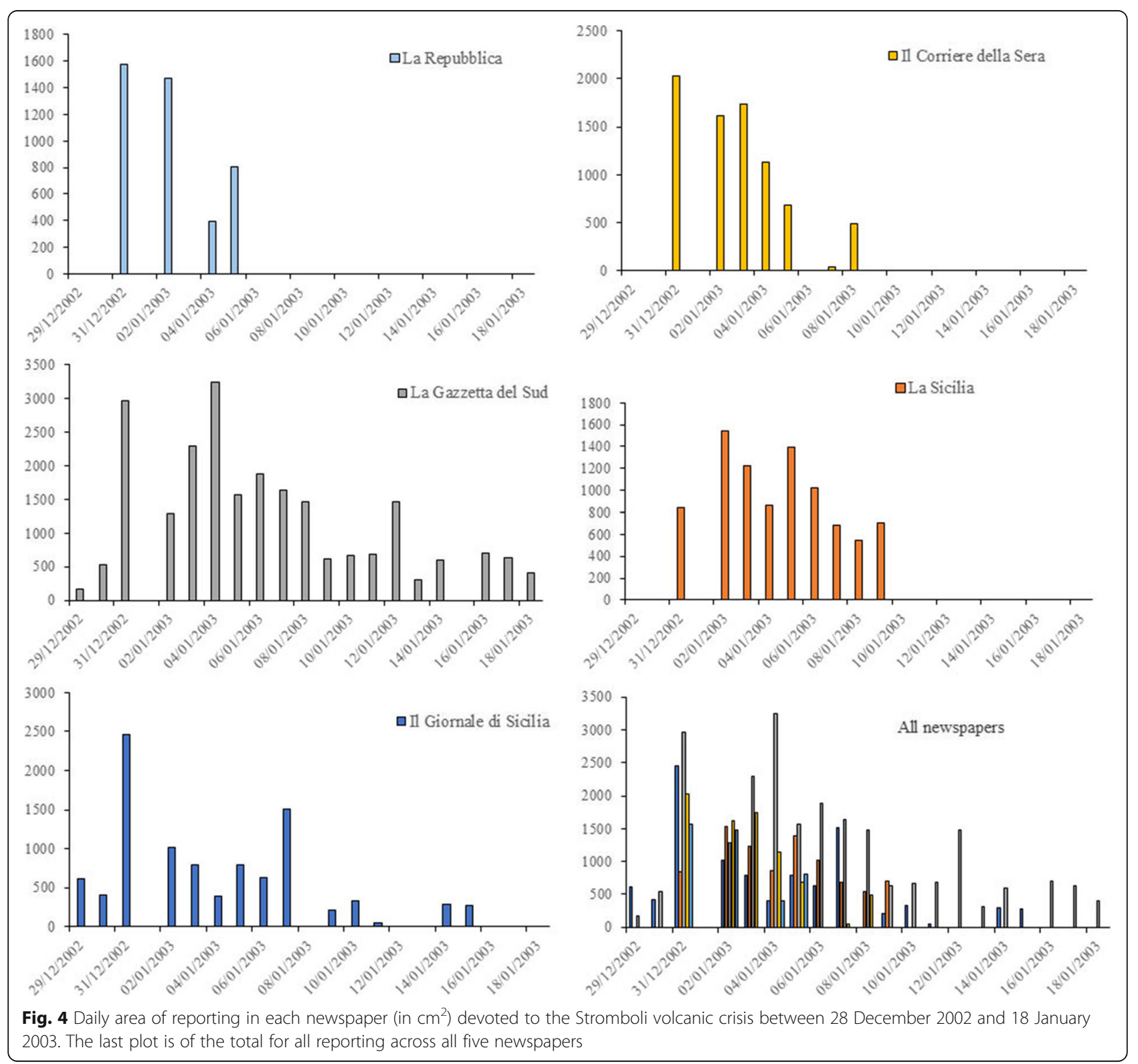


onset of the eruption was only reported in Il Giornale di Sicilia and La Gazzetta del Sud, all newspapers reported the flank collapse and tsunami of 30 December 2002, accounting for this first peak. A second peak in reporting occurred during 2-6 January (Fig. 4). Thereafter, reporting in La Repubblica, Il Corriere della Sera and La Sicilia died out, the last reports occurring on 5, 8 and 9 January in the three newspapers respectively; the crisis was, however, regularly reported in both Il Giornale di Sicilia and La Gazzetta del Sud through to the end of the study period (Fig. 4). Considering all newspapers, we see a rapid rise to peak reporting between 31 December 2002 and 4 January 2003, followed by a steady, waning trend through 18 January (Fig. 4). In terms of information sources, we counted a total of 281 citable sources, where information provision was dominated by scientists $(41 \%)$ and the resident population and tourists (46\%), with hazard managers being under-represented (Fig. 5).

\section{National newspapers}

The total space dedicated to the crisis in La Repubblica and Corriere della Sera covered areas of $4250 \mathrm{~cm}^{2}$ and

\section{Il Corriere della Sera}

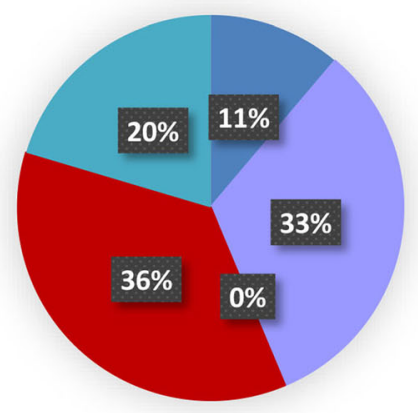

\section{La Repubblica}

La Sicilia

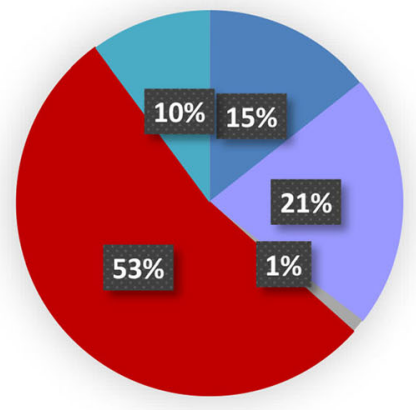

Il Giornale di Sicilia

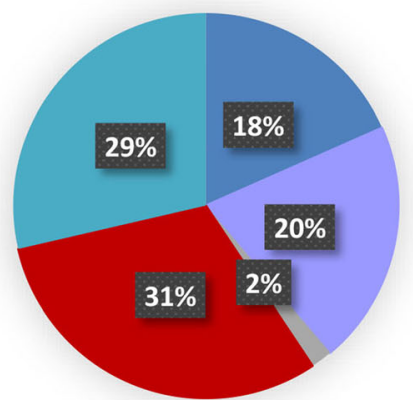

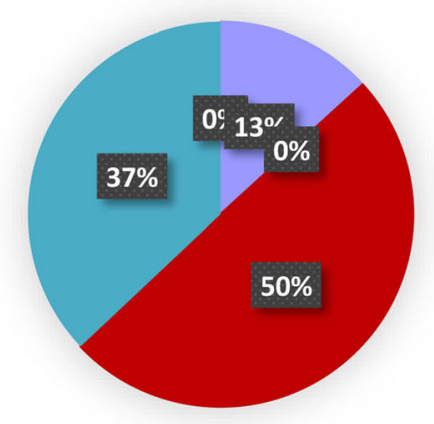

\section{La Gazzetta del Sud}

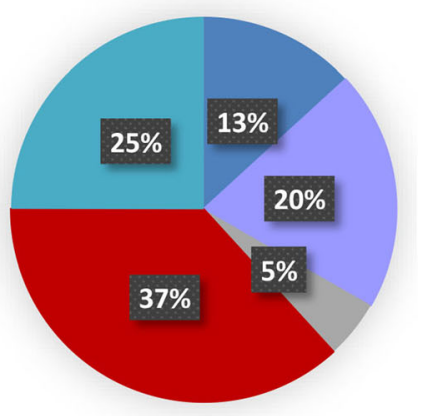

All Newspapers

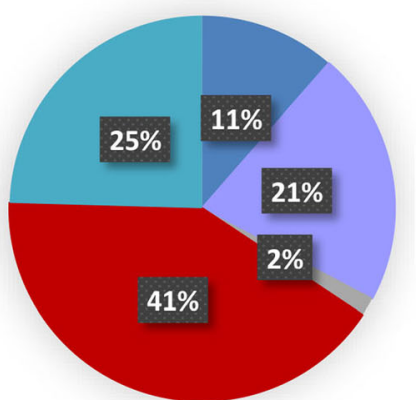

Fig. 5 Relative contribution of each source to all quotes in the newspapers. Red = Scientists; Blue= Miscellaneous (mostly tourists); Dark blue = Hazard managers; Purple $=$ Population; Grey $=$ Responders 
$8000 \mathrm{~cm}^{2}$, respectively (Table 1 ). In both newspapers, the first article appeared on 31 December 2003 following the flank collapse and tsunami of 30 December, meaning that the onset of the eruption was not reported (i.e., the former event was considered newsworthy, yet the latter was not). Continued high levels of coverage were recorded through 5 January, and were related to follow-up on the tsunami event. Sources were dominated by scientists and the population / tourists, with hazard managers not being quoted at-all in La Repubblica (Fig. 5).

A total of 971 words were counted in La Repubblica, and these could be divided into 103 unique meanings, of which 17 words groups accounted for 486 (i.e., 50\%) of all words used (Table 3). These words mostly refer to places/locations and involve terms related to natural phenomena and hazards, with the first four most common words being "Stromboli-Volcano-Terror-Sea"; "collapse" is 6th (with 35 uses) and "tsunami" 7th (30 uses), with "lava" being the only other eruption-related word at equal 14th (15 uses). Instead, a total of 1262 words were counted in Corriere della Sera. These could be divided into 121 unique meanings, of which 19word groups accounted for 629 (i.e., 50\%) of all words used (Table 4). These words, as for the La Repubblica, focused on places/locations and natural phenomena, with the first four being "StromboliTsunami-Volcano-Sea"; after which the only two volcanic hazard words in the list were "landslide" (7th, 31 uses) and "collapse" (19th,17 uses). This reflects a focus on the flank collapse and tsunami, and its local impact, with the eruption itself receiving, instead, secondary attention. This trend was mirrored in the hazard words used in the two newspapers, where the top three were "tsunami-volcano-landslide" for Corriere della Sera and "volcanocollapse-tsunami" for La Repubblica (Fig. 6).

Descriptive words were almost entirely negative. Words such as "fear" and "alarm" appeared 40 and 12 times in La Repubblica. The same two words appeared 30 and 20 times in Corriere della Sera (Fig. 7). We see this effect in the overall word count, where "terror" was the third most used word in La Repubblica (Table 3). A few words with positive connotations, such as "hope" or "luck" appeared in La Repubblica, but only on three and two occasions, respectively. "Optimism" was the only positive word used in Corriere della Sera, a word that appeared just twice.

The reporting focus was thus on the landslide and tsunami, with the events described in negative and alarmist terms, in sensationalized phrases, as can be seen from the headlines and body text phrases themselves. Take the following examples,
Table 3 Top ranked words appearing in La Repubblica, with percentage of all words accounted for by each word group

\begin{tabular}{llll}
\hline Rank & Words & Counts & $\%$ \\
\hline 1 & Stromboli Island & 89 & 9.2 \\
2 & Volcano & 48 & 4.9 \\
3 & Terror / Fear & 40 & 4.1 \\
4 & Sea & 38 & 3.9 \\
5 & Lipari & 36 & 3.7 \\
6 & Collapse & 35 & 3.6 \\
7 & Tsunami & 30 & 3.1 \\
8 & Civil Protection & 29 & 3.0 \\
9 & Sciara del Fuoco & 25 & 2.6 \\
$=10$ & Stromboli Village & 19 & 2.0 \\
$=10$ & Ship & 19 & 2.0 \\
12 & Ginostra & 17 & 1.8 \\
13 & Aeolian Islands & 16 & 1.7 \\
$=14$ & Lava & 15 & 1.5 \\
$=14$ & Port & 15 & 1.5 \\
$=14$ & Coast & 15 & 1.5 \\
$=14$ & Surveillance & 15 & 1.5 \\
Sum & & 486 & 51.6 \\
\hline
\end{tabular}

Table 4 Top ranked words appearing in Corriere della Sera, with percentage of all words accounted for by each word

\begin{tabular}{|c|c|c|c|}
\hline Rank & Words & Counts & $\%$ \\
\hline 1 & Stromboli Island & 84 & 6.7 \\
\hline 2 & Tsunami & 64 & 5.1 \\
\hline 3 & Volcano & 55 & 4.4 \\
\hline 4 & Sea & 43 & 3.4 \\
\hline 5 & Stromboli Village & 40 & 3.2 \\
\hline 6 & Civil Protection & 38 & 3.0 \\
\hline 7 & Landslide & 31 & 2.5 \\
\hline$=8$ & Ship & 30 & 2.4 \\
\hline$=8$ & Terror / Fear & 30 & 2.4 \\
\hline$=8$ & Expert & 30 & 2.4 \\
\hline$=11$ & Sciara del fuoco & 27 & 2.1 \\
\hline$=11$ & Residents & 27 & 2.1 \\
\hline 13 & Lipari & 24 & 1.9 \\
\hline 14 & Aeolian Islands & 23 & 1.8 \\
\hline$=15$ & Houses & 21 & 1.7 \\
\hline$=15$ & Civil Authorities & 21 & 1.7 \\
\hline$=15$ & Coast & 21 & 1.7 \\
\hline 18 & Alarm & 20 & 1.6 \\
\hline 19 & Collapse & 17 & 1.4 \\
\hline Sum & & 629 & 51.2 \\
\hline
\end{tabular}



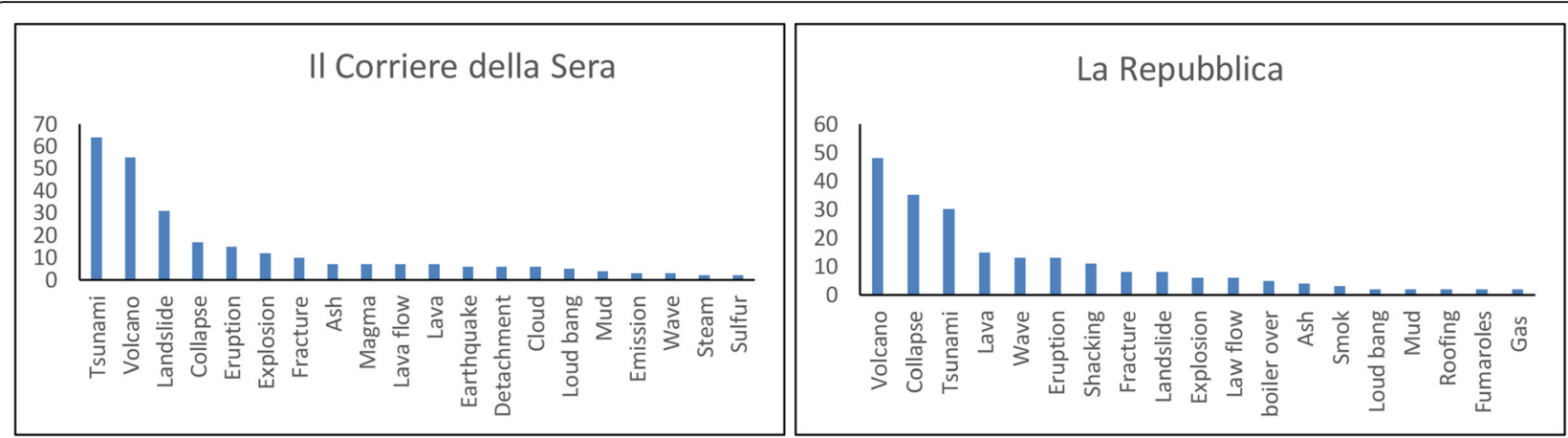

Fig. 6 Frequency distribution of hazard terms used in Corriere della Sera and La Repubblica

- "An anomalous wave terrorizes Stromboli" (Reference 1 (Abbruzzese, 1935), Table 2);

- "Explosion on the volcano, escape from Stromboli" (Reference 2, Table 2).

Journalistic style also resulted in construction of evocative phrases linked to famous historical books, for example,

- "It looked like the hell of the Divine Comedy" (Reference 3, Table 2);

- "A cloud from Dante's circle that floats in the air for an indefinite time and swoops down with force when it is by now mud" (Reference 4, Table 2).

\section{Regional newspapers}

Total space dedicated to the crisis in Gazzetta del Sud, Il Giornale di Sicilia, and La Sicilia was 24,000, 8600 and $8400 \mathrm{~cm}^{2}$ in the three newspapers, respectively (Table 1). In both Gazzetta del Sud and Il Giornale di Sicilia, the first article appeared on 29 December reporting the eruption onset. In Gazzetta del Sud the eruption was announced with the front-page headline:

"Stromboli, record eruption. The lava flows into the sea" (Reference 5, Table 2).

Likewise, the front-page headline in Il Giornale di Sicilia read:

"Stromboli awakens" (Reference 6, Table 2).

Inside, the activity was compared with the effusive eruption of 1985 (References 7-9, Table 2). La Sicilia did not begin reporting on the crisis until the flank collapse and tsunami of 30 December, where reporting in all three regionals peaked on 31 December. Thereafter, Gazzetta del Sud and Il Giornale di Sicilia reported on the eruption through the end of the study period, but La Sicilia followed the nationals in only reporting until 9 January (Fig. 4). As with the national newspapers, sources were dominated by scientists and the population / tourists, with hazard managers again being underrepresented (Fig. 5).
A total of 3017, 1939 and 2065 words were counted in Gazzetta del Sud, Il Giornale di Sicilia, and La Sicilia, respectively. In Gazzetta del Sud, Il Giornale di Sicilia, and La Sicilia, 21, 13- and 19-word groups accounted for by 1537, 956 and 1030 (i.e., 50\%) of all words used (Tables 5, 6 and 7). The words used between the three regional newspapers were similar, and the dominant themes were those of the national newspapers. In support of this, the top four words in Gazzetta del Sud, Il Giornale di Sicilia, and La Sicilia were:

- Stromboli Island, Tsunami, Lipari, Sea, Civil Protection (Table 5);

- Stromboli Island, Tsunami, Volcano, Civil Protection, Sea (Table 6);

- Stromboli Island, Tsunami, Sea, Residents, Civil Protection (Table 7).

The main volcanic hazard focused-on was, as in the national newspapers, collapse, tsunami and local impact, with the word "eruption" not appearing atall in the most-used word group listings of Tables 5, 6 and 7. This, again, was reflected in the hazard words used in each of the newspapers, where the top three were "tsunami-volcano-collapse" for all three newspapers (Fig. 8). However, unlike in the national newspapers, the regional newspaper listings began to record words associated with disaster management and response, such as "civil protection", "residents", "evacuation", "surveillance" and "helicopter", as well as "boats/hydrofoil" (i.e., the means by which people can be taken off of the Island) (Tables 5-7).

All the same, as in the national newspapers, descriptive words were almost entirely negative, with "terror" and "fear" again placing highly (Fig. 7). Descriptive terms were also prone to exaggeration, the voluntary evacuation, for example, being termed an "exodus", the "great escape" or the "great emigration"; and events being 


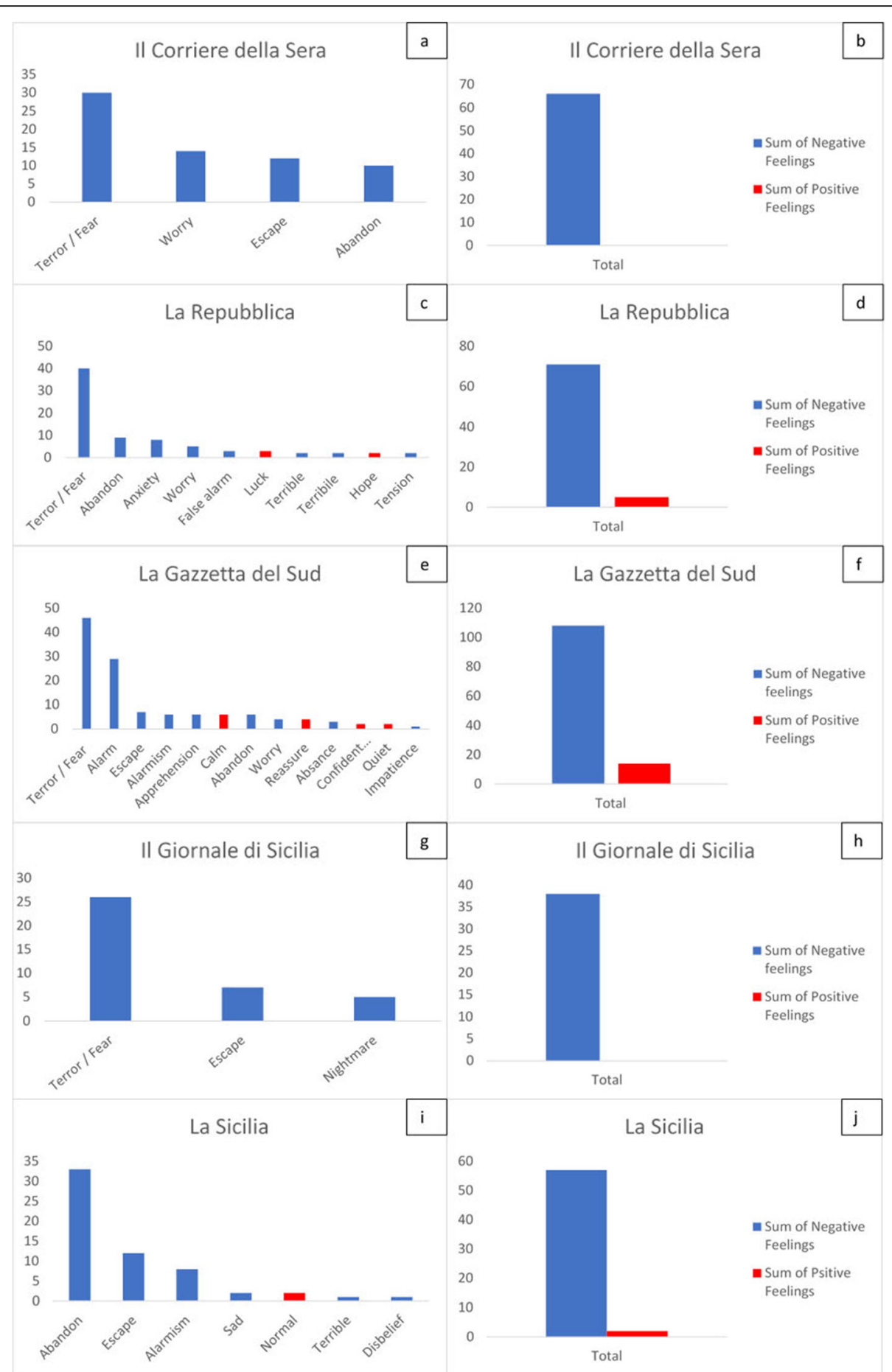

Fig. 7 Frequency distribution of all descriptive terms found in each of the five newspapers analyzed, with classification into "negative" and "positive" connotations

"apocalyptic". Again, this was reflected in the phraseology of headlines and body text. This can be seen, for example, in:

- "On the run from Stromboli" (Reference 10, Table 2);
- "Panic in the Aeolian Islands" (Reference 11, Table 2);

- "Terror in Stromboli" (Reference 11, Table 3).

We note, however, that the tendency to use negative, exaggerated terms only began after the events of 30 
Table 5 Top ranked words appearing in Gazzetta del Sud, with percentage of all words accounted for by each word group

\begin{tabular}{|c|c|c|c|}
\hline Rank & Words & Counts & $\%$ \\
\hline 1 & Stromboli Island & 291 & 9.9 \\
\hline 2 & Tsunami & 143 & 4.7 \\
\hline 3 & Lipari & 130 & 4.2 \\
\hline 4 & Sea & 115 & 3.8 \\
\hline 5 & Civil Protection & 104 & 3.4 \\
\hline 6 & Ginostra & 78 & 2.6 \\
\hline 7 & Sciara del Fuoco & 77 & 2.5 \\
\hline 8 & Residents & 76 & 2.5 \\
\hline 9 & Stromboli Village & 71 & 2.3 \\
\hline 10 & Volcano & 62 & 2.0 \\
\hline 11 & Emergency & 52 & 1.7 \\
\hline 12 & Aeolian Islands & 48 & 1.6 \\
\hline 13 & Collapse & 48 & 1.6 \\
\hline 14 & Terror/Fear & 46 & 1.5 \\
\hline 15 & Yesterday & 45 & 1.5 \\
\hline 16 & Phenomena & 43 & 1.4 \\
\hline 17 & Helicopter & 37 & 1.2 \\
\hline 18 & Messina & 36 & 1.2 \\
\hline 19 & Damage & 35 & 1.1 \\
\hline 20 & Lava & 33 & 1.1 \\
\hline 21 & Landslide & 33 & 1.1 \\
\hline Sum & & 1537 & 52.3 \\
\hline
\end{tabular}

Table 6 Top ranked words appearing in II Giornale di Sicilia, with percentage of all words accounted for by each word

\begin{tabular}{llll} 
group & & & \\
\hline Rank & Words & 262 & $\%$ \\
\hline 1 & Stromboli Island & 110 & 13.5 \\
2 & Tsunami & 85 & 5.7 \\
3 & Volcano & 81 & $4 .^{\prime}$ \\
4 & Civil Protection & 76 & 4.2 \\
5 & Sea & 56 & 3.9 \\
6 & Residents & 53 & 2.9 \\
7 & Lipari & 49 & 2.7 \\
8 & Ginostra & 49 & 2.5 \\
9 & Sciara del fuoco & 48 & 2.5 \\
10 & Experts & 45 & 2.5 \\
11 & Boat & 42 & 2.3 \\
12 & Collapse & 42 & 2.2 \\
13 & Houses & 956 & 2.2 \\
Sum & &
\end{tabular}

Table 7 Top ranked words appearing in La Sicilia, with percentage of all words accounted for by each word group

\begin{tabular}{llll}
\hline Rank & Words & Counts & $\%$ \\
\hline 1 & Stromboli Island & 230 & 11.1 \\
2 & Tsunami & 79 & 3.8 \\
3 & Sea & 75 & 3.6 \\
4 & Residents & 70 & 3.4 \\
5 & Civil Protection & 66 & 3.2 \\
6 & Volcano & 65 & 3.1 \\
7 & Collapse & 55 & 2.7 \\
8 & Lipari & 51 & 2.5 \\
9 & Sciara del Fuoco & 48 & 2.3 \\
10 & Stromboli Village & 44 & 2.1 \\
11 & Terror / Fear & 36 & 1.7 \\
12 & Aeolian Islands & 34 & 1.6 \\
13 & Landslide & 33 & 1.6 \\
14 & Surveillance & 30 & 1.5 \\
$=15$ & Evacuation & 29 & 1.4 \\
$=15$ & 30/12/2002 & 29 & 1.4 \\
$=17$ & Boat + Hydrofoil & 28 & 1.4 \\
$=17$ & Lava flow & 28 & 1.4 \\
19 & Earthquake & 27 & 1.3 \\
Sum & & 1030 & 51.2 \\
\hline & & &
\end{tabular}

December, whereas reporting on 29 December was more soberly phrased (cf. References 5-9 with 10-12, Table 2). This tendency was actually remarked on by interviewees where, for example, the mayor of Lipari was quoted as saying, on 3 January, "I want to say, with the utmost simplicity, to the media not to create unnecessary alarmism, not to try to amplify everything to chase the scoop" (Reference 13, Table 2; see also References 14-15). However, this did not stop the journalistic trend in which we continued to encounter phrases frequently containing the words "fear", "panic", "furiously", "terrible", and "freak" (e.g., References 16-15, Table 2).

\section{Front pages}

Out of the 53 newspaper editions analyzed, 44 reported the eruption of Stromboli in their front page. Of these front page entries, 12 were linked to the landslide risk (as the cause of an "anomalous wave"), followed by the tsunami itself (appearing 8 times), collapse (independent of wave generation, 6 times), the eruption (4 times), weather ( 3 times), lava (2 times), evacuation (1 time) and explosion (1 time). Analyzing the words in front page headlines, we obtain the following word frequencies (in order of most-to-least used words):

1. Stromboli (21 times) 


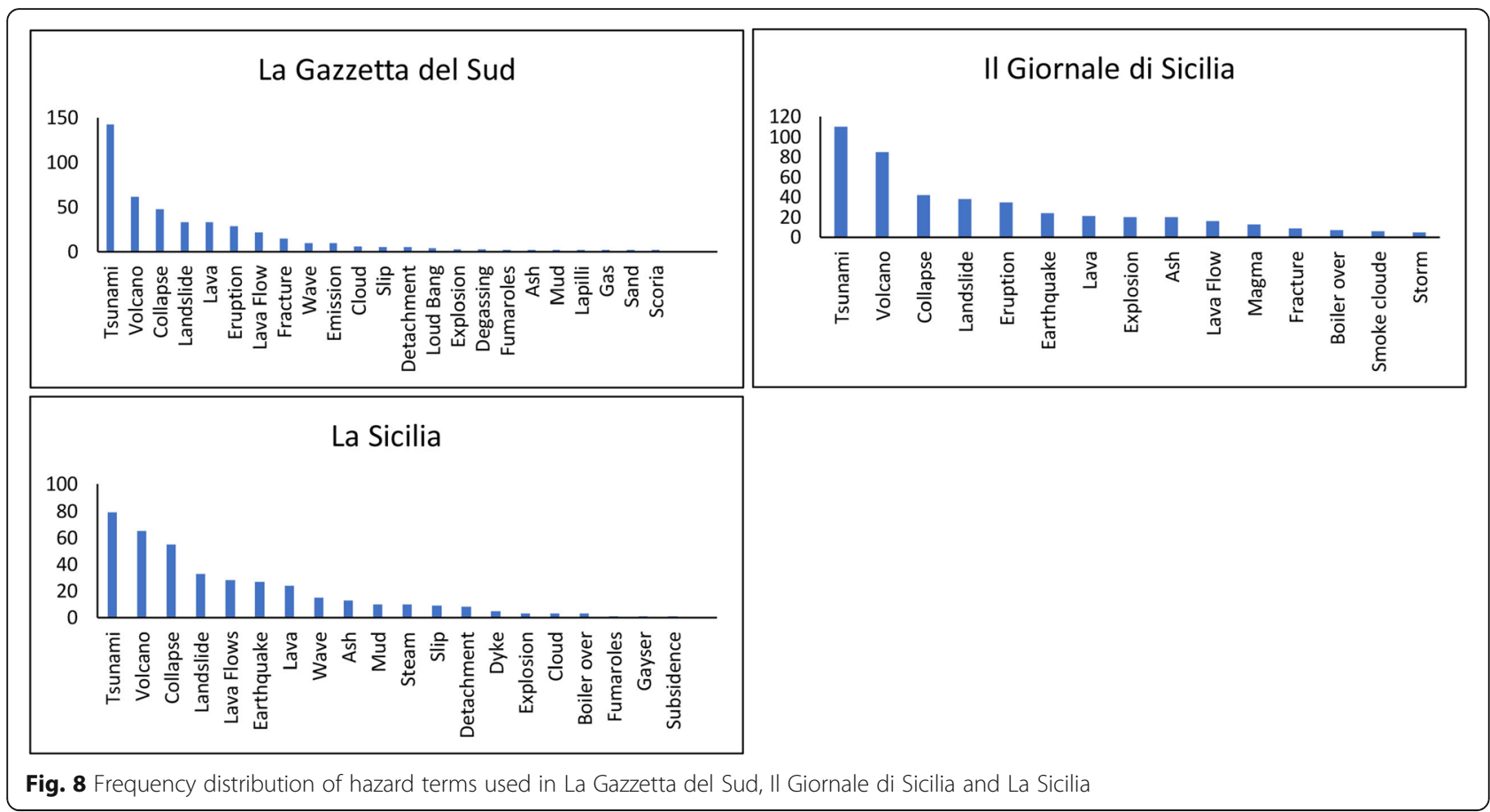

2. Risk (6 Times)

3. Tidal wave (6 times)

4. Fear-Terror-panic (5 times)

5. Alert (4 times)

6. Collapse (4 times)

4. Aeolian Islands (3 times)

7. Escape (3 times)

Thus, again, the key theme delivered by the front page was the landslide/tsunami hazard, with a frame of "fear", "terror" and "panic" being promoted, to engender the need to "escape"; with all words intimately tied to "Stromboli".

Twenty-seven of the front pages carried an image. These could be divided into four groups:

1. Volcano (13 cases): All images belonging to this group portrayed a cloud of steam rising from the sea at the ocean entry, with active lava flow on the Sciara del Fuoco. Predominant colors were the redorange of the lava, the grey or purple of the cloud, and the dark colors (dark brown and black) of the Sciara del Fuoco.

2. Damage (3 cases): These images showed the damage caused by the passage of the tsunami, including boats turned upside down near the walls of houses and gutted houses. They were only shown on 31 December.

3. Evacuation (3 cases): These involved photos of people and means of transportation (helicopter, boats and trucks) used for the rescue, as well as the public figures involved in the response (such as the Mayor of Lipari and head of Civil Protection).

4. The Island (7 cases): This group portrayed Stromboli Island, taken from a distance (off-shore), showing a tranquil island under blue skies with calm seas.

Thus, unlike the text, front page imagery focused on the spectacular lava, the evacuation and the beauty of the island; a theme which was repeated in imagery used for inside page reports. The tsunami and damage thus became a secondary theme in the imagery used, with the main imagery (of categories 1 and 4 ) reflecting postcards for sale on the island (Figs. 2 and 3).

\section{Sources}

In all five newspapers, there was four categories of sources of information:

1. Scientists, mostly from (Istituto Nazionale di Geofisica e Vulcanologia (INGV) and Centro Nazionale di Ricerca (CNR)) whose communications were divided into two types: quotes and interviews. In the quotes, information related to flank instability and the dynamics of landslides and tsunami were given, with verbatim interviews giving more detailed explanations

2. Government representatives (from Civil Protection, the municipality of Lipari and the Sicilian regional government), where bulletins regarding "action 
plans" implemented for the "Stromboli emergency" were also quoted regularly

3. Rescuer actions (by Carabinieri, the fire department, Guardia di Finanza and the municipal police) to help island residents

4. Verbal histories from interviews of residents and tourists, focusing on their impression (feelings, perception) of the emergency

Statements from scientists took up 50\% of the quoted material in La Repubblica and La Sicilia, compared to $30 \%$ in the three other newspapers investigated (Fig. 5). These differences reveal a more technical focus to reporting in La Repubblica and La Sicilia.

\section{Framing actions}

Our analysis reveals that two main hazard types were focused on during the first 3 weeks of Stromboli's 200203 eruption. These were the out-of-the-ordinary events: the landslide/collapse of 30 December, the ensuing tsunami, and the "evacuation". The more common explosive and continuing effusive activity were much less well represented (if reported-on at-all). Subsequently, all events became framed by reports that assumed alarmist tones; the reporting style being of a negative rather than positive tone, engendering "fear" and "terror". This was in spite of an apparent use of sources that focused on scientists, as well as hazard managers and the local population who, at times, were actually quoted as asking the journalists to tone the reporting down.

\section{Landslide/collapse frame}

Although the onset of the eruption itself was only reported in two of the five newspapers considered, the events of 30 December 2002 appeared in all newspapers on 31 December 2002. On this date, several statements by experts appeared explaining the dynamics of the collapse, where some of these statements were linked to illustrative sketches to help readers understand the phenomenon: as, for example, on page 14-15 of La Repubblica on 31 December. Other images, instead, showed spectacular views of the Sciara del Fuoco with clouds of white steam and red/orange lava flows, consistent with the postcard image of Stromboli (Fig. 2).

With the second collapse on 3 January 2003 (which did not actually generate a tsunami), the frame changed. News regarding the second landslide appeared in all newspapers on 4 January with alarmist titles such as,

"A new landslide: hours of fear in the Aeolian Island" (Reference 16, Table 2),
"Stromboli, overwhelmed by panic - Two new landslides, all fleeing: Aeolian now it is psychosis" (Reference 17, Table 2).

Negative words including "fear" and "terror", or phrases such as "high tension" and "anxiety" also began to dominate the text of the regional newspapers.

\section{Tsunami frame}

The tsunami was characterized by images showing the damage caused by the waves, including pictures of damaged boats and houses, streets covered with debris and images of wounded people. This event was negatively framed, by newspapers, with headlines all carrying negative descriptors, such as,

"Freak wave terrorizes Stromboli" (Reference 1 (Abbruzzese, 1935), Table 2);

"Panic in the Aeolian Islands" (Reference 11, Table 2); and

"Terror in Stromboli" (Reference 12, Table 2).

The description of the tsunami was mainly reported through the eyes of the residents and tourists, the tsunami being framed as an "apocalyptic" event heralding the "end of the world". The "end of the world" frame was fueled by the exaggerated and poetic style employed by the journalists themselves. For example, one report contains the following description:

"... the wave ends with a biblical backwash, it gains strength and furiously crashes against the coast, breaking like a tidal wave. This apocalypse started at the fiery Sciara" (Reference 18, Table 2).

Similarly-worded reports can be found across all three regional newspapers examined here, in which use of phrases such as "apocalyptic scenes", the "fury of the elements", and the "rage of fire and the sea" were common. Some articles included superlative-filled eye-witness accounts to support the frame, such as:

"I saw the wave. Very high, immense, powerful. Like in a movie ... " (Reference 19, Table 2; see also Reference 20).

Comparison with previous events was made by the newspapers, in particular with the tsunami generated by Stromboli's eruption of September 1930. However, this was a very different event to that of 2002 and was associated with a paroxysmal explosion associated with pyroclastic density currents that stopped just short of Stromboli village, and tephra fallout which were the cause of four deaths, several injuries, and fires; with the 
tsunami coincident with the explosion accounting for a further two fatalities (Maramai et al., 2005). The 1930 event was, truly, terrifying (La Colla, 1930), and has been ascribed to a depopulation of Stromboli, where the population fell from 2500 to 659 people between 1911 and 1951 (Archivio Storico Eoliano). Based on the comparison with the 1930 lethal event, these negative images were (unjustly) associated with the 2002 eruption, giving little comfort to an already "frightened" population. For example,

"In the last century the volcano had sown death and terror. Here is the chronicle of that terrible morning ..." (Reference 21, Table 2).

Expert statements were reported in less alarmist tones, but quotes confused the readership by highlighting conflicting views among the experts regarding tsunami definitions and possible dynamics. This is a known problem when scientific debate and disagreement is carried out in public during a volcanic crisis (cf. IAVCEI, 1999; Fiske, 1984), where it is the "media appeal of one scientist versus another" that counts. Our study, also, highlights how different words like tidal wave can be used as synonymous by a journalist for a tsunami, when in scientific terms the words do not have the same meaning and in hazard/risk terms very different connotations. This leads to further confusion in the intended meaning of the message released by the experts.

As a result, almost all of the quotations from Island residents pointed to tsunami and the sea (rather than the eruption and the volcano) as their main source of concern. This can be seen, for example, in a statement appearing in Il Giornale di Sicilia on 4 January 2003:

"No, the volcano does not scare me, he has nothing to do with it; it is the sea that causes me fear".

However, more optimistic declarations were also present:

"We saw a huge wave arrive that overwhelmed everything and everyone. Fortunately, there were no victims. It could have been a tragedy. That's the way it goes" (Reference 22, Table 2).

\section{Or}

“... The tidal wave? I remember the tidal wave of 31 December, it destroyed the jetty at Scari. But after that everything returned to normal, and the same will happen again this year. The major source of damage will more likely be the misinformation from the television news rather than the events related to the volcano" (Reference 23, Table 2).

However, such statements were generally eclipsed by the alarmist and sensationalist tone of the writing regarding the tsunami hazard, which failed to link the hazard to the on-going eruption.

\section{The evacuation frame ("escape from Stromboli")}

News of the "evacuation" of Stromboli, which was later clarified as a voluntary evacuation by Civil Protection (Bertolaso et al., 2008a), appeared in all newspaper issues on 31 December 2002. Phrases used to describe the evacuation, besides using the word "escape", were often accompanied by words like "panic" or "terror". Some journalists described it as "the great migration" or an "exodus".

Most of the reported quotes pointed to a confusing picture. On 31 December 2002 La Repubblica reported a statement from the Civil Protection in which a voluntary evacuation plan was described ("A voluntary evacuation plan was triggered" ...). Instead, on 2 January 2003, no mention of evacuation was made, but instead the following statement was given:

"Houses close to places where collapses can occur and houses that could be hit by boulders have been abandoned. There is no evacuation order, but we are considering prohibiting access to the Island .... Of course, those who have left will want to come back, but we advise people to stay away" (Reference 24, Table 2).

Some statements by the Mayor of Lipari also indicated that there was no evacuation in place, but residents were invited to leave the Island as a preventive measure. In Corriere della Sera, an interview with of one of the residents regarding the evacuation reported that the "voluntary evacuation was more like a forced pack-up and follow of the first 11 volunteers". The frame thus assumed a negative tone due to the confusing information and naturally resistant motives among the residents. For example, one resident was quoted as saying,

"Extreme fear. Now many leave. But how do you leave our home, our Island? It is here that we have everything ..." (Reference 25, Table 2).

What was not communicated was that scientists, civil protection and the mayor of Lipari were, during the last days of December 2002 and first days of January 2003, working in close collaboration to implement an effective response and surveillance plan (Bertolaso et al., 2008a,b, 2009); resulting in what can be regarded as one of the 
most dense monitoring arrays on the planet and a blueprint for surveillance. However, inconsistencies and apparent disagreements between various actors did not help clear this issue up. For example, Corriere della Sera noted disagreement between two experts regarding the instability of the Sciara del Fuoco and on the possible occurrence of other collapses (Corriere della Sera, 31/ $12 / 2002$, p. 9) writing that "the statements issued by the two experts, however, are not perfectly in tune". Likewise, a report published on 3 January 2003, entitled "Explosion Risk? - Separated Scientists" (Giornale di Sicilia, 03/ $01 / 2003$, p. 3), focused on the different points of view of two scientific groups regarding the potential for a flank failure to generate a major explosive event (see Reference 29 of Table 2). The result was a feeling that "anything can happen" (Reference 30, Table 2).

\section{Attempts to address the alarmist frame}

Many statements published by the newspapers themselves after 2 January 2003 actually contained complaints against the journalists for creating alarmism and for giving erroneous information about the event. In La Sicilia, for example, statements relating to the quality of the reporting appeared multiple times. On 3 January 2003, the mayor of Lipari accused the journalists of creating too much alarmism and of amplifying the news to increase newspaper sales (Reference 13, Table 2). On 5 January 2003, the health minister accused journalists of damaging Island tourism and the economy (Reference 31, Table 2). In angrier tones, one of Stromboli's residents declared:

"We're pretty 'pissed off' with journalists because they keep writing nonsense, like we've all escaped, that the Island risks to sink to the bottom of the sea and stuff like that. Those who left did not escape but made a prudent choice based on the advice of civil protection." (Reference 26, Table 2).

In both Il Giornale di Sicilia and La Gazzetta del Sud, residents accused journalists of damaging the Island economy with their "inflated articles" (Reference 32, Table 2) in which they were accused of depicting Stromboli as "a bomb" ready to explode. For example, one resident was quoted as saying,

"You can't extrapolate phrases from complex discussions about theoretical risks, take them and portray them as a looming event" (Reference 27, Table 2).

Further factual inconsistencies were found in our analysis, and these may lead us to further question newspaper credibility during reporting of the crisis, and these are given in Supplement 2. However, whatever the pressure, all newspaper agendas remained unaltered, with slant and spin remaining alarmist, sensationalist and unsupportive of attempts to calm a "frightened" population.

\section{Discussion sum-up}

News media are always interested in human stories and conflict, and less so on geophysical events and natural processes, unless they are of particularly high magnitude or impact (Harcup 2009; Harris 2015). Indeed, bad news (stories with negative overtones, such as conflict, tragedy, chaos, confusion and/or suffering), especially involving the "power elite" (i.e., powerful individuals, organizations or institutions) are two of the ten main new values listed by Harcup (2009) as being applied by modern news agencies. As a result, reporters will focus on conflicts between scientists and agencies/institutions, claims about impacts (especially economic), and the suffering of local and visiting (tourist) populations. Thus, it is essential to avoid such conflict in public, which will provide the reporter with the required news value to generate "a story". At the same time, though, the reporter will need to (indeed must and has to) use a language that is not only accessible, but also readable, understandable and entertaining for the layperson. Thus, such language must be used in communications, a language that recognizes the translation need of the media filter. Social media has emerged since the 2002-03 Stromboli crisis as the immediate means of communicating and framing a natural disaster (Williams and Krippner, 2018), as have near-real-time news streams. However, these suggestions equally apply for social media (e.g., individual-tweet style, messages from inhouse scientists), press releases, and on-line situation reports. That is, there is a need for all scientists involved in the crisis to echo the same message in terms of situation-reality, rather than voice their own interpretations and disagreements. Scientific debate, albeit healthy, must be kept in-house during the crisis and response itself, and the temptation to trump rival scientific findings avoided. Probably, a press office linked to a regularly uptodated and centralized information site, where the population and journalists know they can find usable, reliable and suitably written/framed information is a good idea (as pointed out as early as in 1999 by the IAVCEI Subcommittee for Crisis Protocols). Because scientists and responders are usually too busy to deal with such outreach during a crisis, it is a recommendation that a competent office (or outreach officer) needs to be charged with this dedicated role, with information provided via a suitably designed and attractive web-site (Christensen, 2010). Scientific publication can then follow, once (as a community together) we have dealt with the crisis. 
In the case examined here, the accusations of alarmism from Stromboli's residents are also likely a result of the damage such a frame makes to livelihoods, especially if tourists are frightened away from a small island dependent on tourism. Such an effect was found by Donovan et al. (2018) after the non-eruption of Zao in Japan in 2014-15 where people complained about "rumor damage" from the media and linked this to a lack of robust scientific information from government entities. These issues will be inflated by lack of information, or clarity of information, from the responsible institution; which was case for Stromboli's 2002-03 eruption where information was not reported or communicated by the monitoring and responding community in a clear or consistent way.

In the long run the event did, however, increase awareness of volcanic hazard on Stromboli, and led to changes in hazard management on Stromboli, an enormous improvement of the monitoring network and response system, communication, signage, outreach and education (Bertolaso et al. 2008a, b, 2009). As a result, it seems that, from a cursory analysis of the news media during the events on Stromboli during the summer of 2019, this has had a positive effect (see Appendix). Thus, to assess the effects of improved communication since the 2002-03 eruption, implementation of a content analysis (following the model laid out here) of media-based information sources before and after content analyses, as well as discourse analysis, should be applied to the 2019 eruption.

\section{Conclusion}

The coverage of Stromboli's 2002-2003 eruption by the five newspapers considered here was mostly dictated by the scoop-potential of the event. Indeed, the first, low profile effusive phase (28 December 2003) was not deemed sufficiently newsworthy to be covered in three of the five newspapers, including one of the regionals that cover Stromboli in its catchment. The events were likely not sufficiently "out-of-the-ordinary" considering Stromboli's persistent activity. They were deemed simply as a repetition of the 1986 eruption (Reference 7, Table 2), thereby not meeting the news values that would select the event for publication. However, on 30 December 2002 two unexpected, spectacular and damaging events, a landslide and a tsunami, occurred. These two high-impact events were the cause of a sudden increase in reporting, because the events met the news values of all five newspapers. However, this sudden increase in reporting was also associated with exaggeration and sensationalism, the events often being portrayed in poetic and apocalyptic terms.

Further, the scientific sources, despite their widespread use (up to $45 \%$ of information sources in some cases) were reported confusingly and in terms of conflicting opinion and argument. The majority of quotes were setup in an "alarmist" or even "catastrophic" manner, with strong, negative words such as "apocalypse", "hell", and "fear" used as descriptors. A greater amount of material from the hazard management grouping (i.e., government representatives), which typically made up less than $20 \%$ of the quoted material, may have aided in setting the record straight. However, this may not have helped-as even self-confessed alarmism and exaggeration (i.e., published complaints about the tone of the reporting) did not affect the reporting slant and spin. Thus, even in well-informed journalism, the newspaper agenda may be so entrenched that reporting in support of effective hazard management may be impossible to expect.

From the analysis of the Stromboli case it appears that newspaper treatment of surprising or out-of-the ordinary events may help with exaggeration and sensationalism. This will be accentuated in national media sources, who will not report the more mundane events, but instead will focus on the out-of-the-ordinary, as was the case here for the under-reporting of the onset of lava flow, but full reporting of the landslide and tsunami. Thus, in such cases, we may need to prepare for, and to some degree expect, little support from the media toward a correct framing of the hazard, or any help to coordinate and ease the population through appropriate hazard communication, at least in the case of Stromboli. In this context, it is particularly important to use an adequate language that can be understood by the great majority of the population with a minimum content of technical words that can be mis-translated or misdefined. The high credibility of the scientific group in charge of the risk evaluation and recommendations is essential for a quick response to warning and for the success of an emergency plan. To prevent information mishaps, it is thus best to also keep scientific debate inhouse, and seek out a one-voice spokesperson so as to give a single univocal message, while avoiding handing the media material to further exaggerate the catastrophe frame (e.g. Harris, 2015; Harris and Villeneuve, 2018a, b). This view is also shared in literature by, for example, Hincks et al. (2014) and has long been proposed as one of the pillars of risk communications for people in charge at Volcanological Observatories (IAVCEI Subcommittee for Crisis Protocols, 1999).

The media play an increasingly important, sometimes negative, role in hazard management, as there is a tendency to over-emphasize any discrepancy between scientists or between scientists and authorities. Therefore, the spokespeople of the scientific group and the authorities become crucial in conveying the best estimate of any dangers and existing countermeasures. In transmitting this information, spokespeople should take into account 
that the attitude of the local media is generally different from those that have national scope, as highlighted in this study. In fact the regional newspapers described the events of 2002-2003 with more alarmist and negative tones, thus causing problems also for the economy of the Island. However, as indicated by Kitzinger and Reilly (1997), reporting risks and event responses to the mass media needs to be influenced by what journalists perceive to be relevant to themselves, their audiences and their editors (Kitzinger, 1999).

\section{Appendix}

\section{Note added in correction}

While this paper was in review/correction, two paroxysms occurred on Stromboli on 3 July and 28 August 2019, respectively. Both fed plumes to several kilometers in height and generated pyroclastic density currents that advanced $1 \mathrm{~km}$ from the coastline, while the subsquent fallout of incandescent pyroclastic material rapidly igniting vegetation on the flanks of the volcano, resulting in one fatality. On the day of each event, we made a cursory analysis of the on-line stream of news from Il Corriere della Sera, La Repubblica, and La Gazzetta del Sud, as well as the website hosted by the Italian television news channel, RaiNews (http://www.rainews.it/). We found many improvements in the presentation of the news. The changes were particularly evident in La Gazzetta del Sud and on the Rai-News site, in which the news was reported in a more objective, correct and technical way, with less alarmist tones and sensationalist frames. For example, on 03/07/2019, Rai-News posted a factual piece entitled "Stromboli, explosions from the crater: one dead and one injured. Some tourists escape to the sea." (esplosioni dal cratere: un morto e un ferito. Alcuni turisti scappano in mare). On $28 / 07 / 2019$, a posting was made under the equally objective heading: "Strong explosion at Stromboli, lots of fear but no one injured" (Forte esplosione a Stromboli, tanta paura ma nessuno ferito).

Most news sources also appeared to know where to go for appropriate, well-informed quotes (including Università di Firenze-LGS, INGV, Università di Roma, and Civil Protection). For example, on 03/07/2019 Rai-News posted a technical piece entitled "Stromboli, INGV: explosions among the strongest ever registered" (explosion tra più forte mai registrate). Likewise, Il Corriere della Sera website led with "Stromboli trembles, explosions from the crater: excursionist dead, another injured. Tourists in the sea" (Trema Stromboli, esplosioni dal cratere: escursionista muore, un altro è ferito. Turisti in mare, downloaded 03/07/2019). Associated images were of the on-going phenomena (the plume, pyroclastic density currents, lava flows and fires), and those of the island were actual, i.e., showing Stromboli under shrouded in smoke and gray/brown fume, with the plume towering above the island and pyroclastic flows running away from it. Follow-up on 04/07/2019 involved report of a small (magnitude 2) earthquake during the night, a suitably respectful obituary for the lost hiker, and situation reports regarding the fires and response (including dispatch of a large coastguard cutter and firefighting planes (Canadair fire bomber CL-415).

It has to be noted, though, that these events were very different from those accompanying the 2002-2003 eruption. The events were major explosions with high $(>4 \mathrm{~km}$ ) eruption plumes and far-reaching (for an island just $5 \mathrm{~km}$ wide) pyroclastic density currents with sudden onset which, as in the headline of Il Corriere della Sera of 29 August 2019: "Stromboli, fear and anger", genuinely and naturally did instill fear (and an element of anger and frustration, as this was the height of the lucrative tourist season). Measures regarding restrictions were well, clearly, consistently and correctly communicated. Interviews reported with residents during these two paroxysms also underlined that the greatest fear was the tsunami (rather than the volcano). However, expert quotes (following the reaction of tourists on the beach on 03/07, who ran into the water to escape) pointing out that, as hard as it is to do given the ongoing eruptive event, one should run towards the volcano and uphill; as the biggest threat is the tsunami that will arrive from the sea (RaiNews, 03/07/2019). Especially in regards to the tsunami hazard. It has to be noted that, after the events of 2002-2003, there was a major effort to improve the monitoring array, especially in regards to the tsunami hazard, and to improve communication, signage and education. This, along with the memory of the 2002-03 (as well as the 2007) events, appears to have led to a more informed approach by journalists, as well as the sources, to result in the media outlets analyzed evolving into a much-improved information source.

\section{Supplementary information}

Supplementary information accompanies this paper at https://doi.org/10. 1186/s13617-020-00094-0.

Additional file 1. Frequency of word

Additional file 2. Inconsistencies that support credibility issues Additional file 3. Features of Newspapers selected for content analysis

\section{Acknowledgements}

We thank the Agence Nationale de le Recherche which funded both the LAVA and RiskAdapt research projects that supported this work. This work benefited from the comments of Amy Donovan and an anonymous reviewer, who helped us refine and develop our arguments. We also acknowledge the support received from the Agence Nationale de la Recherche of the French government through the program "Investissements d'Avenir" (16-IDEX-0001 CAP 20-25). 


\section{Author's contributions}

The authors have reviewed this manuscript. All authors approved the final manuscript

\section{Funding}

This worked was funded by the Agence National de le Recherche (ANR: www.agence-nationale-recherche.fr) through project ANR-RiskAdapt as well as ANR-LAVA (ANR Program: DS0902 2016; Project: ANR-16 CE39-0009). This is ANR-RiskAdapt contribution no.1, and ANR-LAVA contribution no.13.

\section{Availability of data and materials}

Additional file 1 Frequency of word.

Additional file 2 References and quotes from Newspapers.

Additional file 3 Features of Newspapers selected for content analysis.

\section{Competing interests}

The authors declare that they have no competing interests.

\section{Author details}

'Dipartimento di Scienze Geologiche, Universita' di Roma TRE, Largo S. Leonardo Murialdo 1, 00146 Rome, Italy. ${ }^{2}$ Université Clermont Auvergne, CNRS, IRD, OPGC, Laboratoire Magmas et Volcans, F-63000 Clermont-Ferrand, France.

Received: 18 July 2019 Accepted: 24 March 2020

Published online: 06 May 2020

\section{References}

Abbruzzese D (1935) Attività dello Stromboli dal 1930 al 1934. Boll Soc Sismol XXIII:3-4

Barberi F, Rosi M, Sodi A (1993) Volcanic hazard assessment at Stromboli based on review of historical data. Acta Vulcanol 3:173-187

Barclay J, Haynes K, Mitchell T, Solana C, Teeuw R, Darnell A, Crosweller HS, Cole P, Pyle D, Lowe C, Fearnley C, Kelman I (2008) Framing Volcanic Risk communication within Disaster Risk Reduction: Finding Ways for the Social and Physical Sciences to Work Together: Fig. 1. Geol Soc Lond, Spec Publ 305(1):163-177. https://doi.org/10.1144/SP305.14

Bertolaso G, Bonaccorso A, Boschi E (2008b) Scientific community and civil protection synergy during the Stromboli 2002-2003 eruption. In: The Stromboli Volcano: An integrated study of the 2002-2003 eruption, AGU Monograph, vol 182, pp 387-397

Bertolaso G, De Bernardinis B, Bosi V, Cardaci C, Ciolli S, Colozza R, Cristiani C, Mangione D, Ricciaedi A, Rosi M, Scalzo A, Soddu P (2009) Civil protection preparedness and respose to the 2007 eruptive crisis of Stromboli volcano. Italy J Volcanol Geotherm Res 182:269-277

Bertolaso G, De Bernardinis B, Cardaci C, Scalzo A (2008a) Stromboli ( 2002-2003 ) Crisis Management and Risk Mitigation Actions. In: The Stromboli Volcano: An integrated study of the 2002-2003 eruption, AGU Monograp, vol 182, pp 373-385

Block L.G., Keller P.A. When to accentuate the negative: the effects of perceived efficacy and message framing on intentions to perform a health-related behavior. J Mark Res 1995. https://doi.org/https://doi.org/10.2307/3152047

Bonaccorso A., Calvari S., Garfi G., Lodato L., Patanè D. Dynamics of the December 2002 flank failure and tsunami at Stromboli Volcano inferred by Volcanological and geophysical observations. Geophys Res Lett 2003; 30 (18): 28-31. https://doi.org/https://doi.org/10.1029/2003GL017702

Boykoff M.T. Flogging a Dead Norm? Newspaper Coverage of Anthropogenic Climate Change in the United States and United Kingdom from 2003 to 2006." Area. 2007; https://doi.org/https://doi.org/10.1111/j.1475-4762.2007. 00769.x

Bretton R.J., Gottsmann J., Aspinall W.P., Christie R. Hazard communication by volcanologists: part 1 - framing the case for contextualisation and related quality standards in volcanic hazard assessments. J Appl Volcanol 2018; 7:9 https://doi.org/https://doi.org/10.1186/s13617-018-0077-x

Burton M, Calvari S, Spampinato L, Lodato L, Pino N. A., Marchetti E., Muré F. Dynamics of Strombolian activity. In the Stromboli Volcano: an integrated study of the 2002-2003 eruption, AGU Monograph 2008; 182, 93-104

Capaldi G, Guerra I, Lo BA, Luongo G, Pece R, Rapolla A, Scarpa R, Del Pezzo E, Martini M, Ghiara MR, Lirer L, Munno R, La Volpe L (1978) Stromboli and its 1975 eruption. Bull Volcanol 41-3:259-285

Cavallaro C., Cincotta R. Stromboli. Sagep editrice (Genova). 1991. p. 165
Chua L. A Nonlinear Dynamics Perspective of Wolfram's New Kind of Science :(Volume VI) (World Scientific Series on Nonlinear Science Series A Book 85). Ed. Società editrice Affinità Elettice; 2013. p. 112,121,122,124

Clark G., Bonetto C. Sicilia. Ed. Lonely Planet; 2017

De Fino M, La Volpe L, Falsaperla S, Frazzetta G, Neri G, Francalanci L, Rosi M, Sbrana A (1988) The Stromboli eruption of December 6, 1985-April 25, 1986: volcanological, petrological and seismological data. Rend Soc Ital Mineral Petrol 43:1021-1038

Di Benedetto M (2017) II vulcano in mezzo al mare. Ed Strombolibri

Doyle E.E.H., McClure J., Paton D., Johnston D.M. Uncertainty and decision making: volcanic crisis scenarios. International Journal of Disaster Risk Reduction. 2014; 10: 75-101. https://doi.org/https://doi.org/10.1016/j.jdrr. 2014.07.006

Elo S., Kyngäs H. The Qualitative Content Analysis Process." J Adv Nurs 2008; 62 (1): 107-15. https://doi.org/https://doi.org/10.1111/j.1365-2648.2007.04569.x

Fearnley C. J, Bird D.K., Mcguire W.J. Advances in Volcanology Observing the Volcano World. 2018. https://doi.org/ISSN 2364-3285

Fiske R. Volcanologists, journalists, and concerned local public: a tale of two crises in the Eastern Caribbean, in: Explosive Volcanism: Inception, Evolution, and Hazards. Studies in Geophysics, ed. F. Boyd, National Academy Press, Washington DC. 1984; p. 170-176

Gaillard J.C., Dibben C.J.L. Volcanic risk perception and beyond. J Volcanol Geotherm Res2008; 172 (3-4): 163-169. https://doi.org/https://doi.org/10. 1016/j.jvolgeores.2007.12.015

GAO - Program Evaluation and Methodology division. In Content Analysis: A Methodology for Structuring and Analyzing Written Material, edited by Brian P. Crowley and Joseph F. Delfico. Illinois state University.1996

Harcup T. Journalism: principles and practice (second edition). Sage, Los Angeles; 2009. p. 244

Harris A.J.L. Forecast communication through the newspaper part 1: framing the forecaster. Bull Volcanol 2015; 77:29. https://doi.org/https://doi.org/10.1007/ s00445-015-0899-x

Harris A.J.L., Gurioli L., Hughes E.E., Lagreulet S. Impact of the Eyjafjallajökull Ash Cloud: A Newspaper Perspective. Journal of Geophysical Research: Solid Earth. 2012;117(3). https://doi.org/10.1029/2011JB008735.

Harris A.J.L., Villeneuve N. Newspaper Reporting of the April 2007 Eruption of Piton de La Fournaise, Part 2: Framing the Hazard. Journal of Applied Volcanology. 2018a; 7 (1). https://doi.org/https://doi.org/10.1186/s13617-018-0072-2

Harris A.J.L., Villeneuve N. Newspaper reporting of the April 2007 eruption of piton de La Fournaise part 1: useful information or tabloid sensationalism? J Appl Volcanol 2018b; 7 (1): 4. https://doi.org/https://doi.org/10.1186/s13617018-0073-1

Haynes K., Barclay J., Pidgeon N. Whose reality counts? Factors affecting the perception of volcanic risk. J Volcanol Geotherm Res 2008; 172 (3-4): 259272. https://doi.org/https://doi.org/10.1016/j.jvolgeores.2007.12.012

Hicks A., Armijos M.T., Barclay J., Stone J., Robertson R., Cortés G.P. Risk Communication Films: Process, Product and Potential for Improving Preparedness and Behaviour Change." International Journal of Disaster Risk Reduction 2017 Jan 23: 138-51. https://doi.org/https://doi.org/10.1016/j.jjdrr. 2017.04.015

Hincks T.K., Komorowski J.C., Sparks S. R, Aspinall W.P. Retrospective Analysis of Uncertain Eruption Precursors at La Soufrière Volcano, Guadeloupe, 1975-77: Volcanic Hazard Assessment Using a Bayesian Belief Network Approach. Journal of Applied Volcanology. 2014; 3 (1). https://doi.org/https://doi.org/10. 1186/2191-5040-3-3

IAVCEI Subcommittee for Crisis Protocols. Professional conduct of scientists during volcanic crises. Bulletin of Volcanology. 1999; 60:323-334

Joseph J.K., Karunakaran Akhil Dev, Pradeepkumar A.P., Mohan M. Big Data Analytics and Social Media in Disaster Management. Integrating Disaster Science and Management: Global Case Studies in Mitigation and Recovery. 2018 Apr; 28794. https://doi.org/https://doi.org/10.1016/B978-0-12-812056-9.00016-6

Katzman N (1972) Television soap operas: what's been going on anyway? Public Opinion Quarterly 36(2):200-212

Kitzinger J. Researching risk and the media. Health, Risk and Society 1999; 1 (1): 55-69. https://doi.org/https://doi.org/10.1080/13698579908407007

Kitzinger J., Reilly J. The rise and fall of risk reporting: media coverage of human genetics research, 'false memory syndrome' and 'mad cow disease'. Eur J Commun 1997; 12 (3): 319-350. https://doi.org/https://doi.org/10.1177/ 0267323197012003002

Krippendorff K. Validity in Content Analysis." Computerstrategien Für Die Kommunikationsanalyse 1980 
La Colla V. L'eruzione dello Stromboli nel 1930. [cited 2010 Feb 13]. Available from: http://www.archiviostoricoeoliano.it/sites/www.archiviostoricoeoliano.it/ files/La\%20Colla.pdf

Leiss $W$. Three phases in the evolution of risk communication practice. The ANNALS of the American Academy of Political and Social Science 1996; 545 (1): 85-94. https://doi.org/https://doi.org/10.1177/0002716296545001009

Leonard G.S., Stewart C., Wilson T.M., Procter J.N., Scott B. J, Keys H. J, Jolly G. E, Wardman J. B, Cronin S.J., McBride S.K. Integrating multidisciplinary science, Modelling and impact data into evolving, Syn-event volcanic Hazard mapping and communication: a case study from the 2012 Tongariro eruption crisis, New Zealand Journal of Volcanology and Geothermal Research 2014. https://doi.org/https://doi.org/10.1016/j.jvolgeores.2014.08.018

Linville P.W., Fischer G. W, Fischhoff B. AIDS risk perceptions and decision biases In The Social Psychology of HIV Infection 2015. https://doi.org/https://doi. org/10.4324/9781315722924

Lippmann W. Public opinion. BN Publications. 2008. p. 319

Loughlin S.C., Sparks S., Brown S.K., Jenkins S.F. Vye-Brown C. Global volcanic hazards and risk. Cambrige U 2015

Maramai A, Graziani L, Tinti S (2005a) Tsunamis on the Aeolian Islands (southern Italy): a review. Mar Geol 215:11-21

Maramai A, Graziani L, Tinti S (2005b) Near- and far-field survey report of the 30 December 2002 Stromboli (southern Italy) tsunami. Mar Geol 215:93-106

Marca M. Sicilie. Le Guide Vert, Michelin. Frence: Boulogne Billancourt. 2019. p. 4.

Mathien M (1986) La presse quotidienne régionale. Presses Universitaires de France, Paris, p 127

McClure J., Sibley C.G. Framing effects on disaster preparation: is negative framing more effective? Australas J Disaster Trauma Stud 2011 (1)

McCombs M (2014) Setting the agenda, (2nd ed). Polity Press, Cambridge, p 209

McCombs M, Shaw DL (1972) Agenda-setting function of mass media. Publ Opin Q 36(2):176-187

Naccarato JL, Neuendorf KA (1998) Content analysis as a predictive methodology: recall, readership, and Evauations of business-to-business print advertising. J Advertising Res 38(3):19-33

Neuendorf K.A. The content analysis guidebook. Thousand Oak Sage. 2002. p. 301

P MC-DPC. Benvenuti sul vulcano attivo piu bello del mondo. Dipartimento della Protezione Civile (Romas). 2008. p. 17

Pino NA, Ripepe M, Cimini GB (2002) The Stromboli volcano landslides of December 2002: a seismological desription. Geophys Res Lett 31:L02605. https://doi.org/10.1029/2003GL018385

Rachelli G. L'isola di Stromboli. Ed: Oreste Ragusi (Milazzo). 1998. p. 63

Reese S.D., Gandy O.H., Grant A.E. Framing public life: perspectives on media and our understanding of the social world. Focus. 2001. https://doi.org/https:// doi.org/10.4324/9781410605689

Ripepe M, Delle DD, Harris AJL, Marchetti E, Ulivieri G (2008) Dynamics of Strombolian activity. In the Stromboli Volcano: an integrated study of the 2002-2003 eruption. AGU Monograph 182:39-48

Rowe G., Frewer L. Sjöberg L. Newspaper reporting of hazards in the UK and Sweden. Public Underst Sci 2000; 9 (1): 59-78. https://doi.org/https://doi.org/ 10.1088/0963-6625/9/1/304

Sigurdsson H., Houghton B., McNutt S. R., Rymer H. Stix J. eds. Encyclopedia of Volcanoes (2nd ed.) Vol. 91. London: Academia Press. 2015. p. 915-1283

Stieglitz S., Mirbabaie M., Ross B., Neuberger C. Social Media Analytics Challenges in Topic Discovery, Data Collection, and Data Preparation. International Journal of Information Management 39. 2018; 156-68. https:// doi.org/https://doi.org/10.1016/j.ijinfomgt.2017.12.002

Struck A. Volcano tourism and its influence on the territory of Mount Etna (Italy) - Explored with disgressions to Stromboli (Italy). In ErfurtCooper P, Cooper M. Volcano and geothermal tourism: sustainable geo-resources for leisure and recreation. 2010. Chapter 15, p. 221232

Tinti S., Armigliato A., Manucci A., Pagnoni G., Tonini R., Zaniboni F., Maramai A., Graziani L. The double lanslide-induced tsunami. In The Stromboli Volcano: An integrated study of the 2002-2003 eruption, AGU Monograph. 2008; 182, 147-157

Tinti S, Maramai A, Armigliato A, Graziani L, Manucci A, Pagnoni G, Zaniboni $F$ (2006a) Observations of physical effects from tsunami's of December 30, 2002 at Stromboli volcano, southern Italy. Bull Volcanol 68:450-461

Tinti S, Pagnoni G, Zaniboni F (2006b) The landslides and tsunamis of the $30^{\text {th }}$ December 2002 in Stromboli analysed through numerical simulations. Bull Volcanol 68:462-479
Vu H.T., Guo L., McCombs M.E. 2014. Exploring "the world outside and the pictures in our heads": a network agenda-setting study. J Mass Commun Q 91:669-686. doi:https://doi.org/10.1177/1077699014550090

Williams R., Krippner J. The use of social media in volcano science communication: challenges and opportunities. Volcanica. 2018; 1.2: i-viii

Wilson K (1995) Mass media as sources of global warming knowledge. Mass Comm Review 22:75-89

\section{Publisher's Note}

Springer Nature remains neutral with regard to jurisdictional claims in published maps and institutional affiliations.
Ready to submit your research? Choose BMC and benefit from:

- fast, convenient online submission

- thorough peer review by experienced researchers in your field

- rapid publication on acceptance

- support for research data, including large and complex data types

- gold Open Access which fosters wider collaboration and increased citations

- maximum visibility for your research: over $100 \mathrm{M}$ website views per year

At BMC, research is always in progress.

Learn more biomedcentral.com/submissions 